\title{
5. AN INTERPRETATION OF CONTRASTING NUCLEATION AND GROWTH HISTORIES FROM THE PETROGRAPHIC ANALYSIS OF PILLOW AND DIKE CHILLED MARGINS, HOLE 504B, DEEP SEA DRILLING PROJECT, LEG 831
}

\author{
Pamela D. Kempton, Department of Geological Sciences, Southern Methodist University²
}

\begin{abstract}
Petrographic observations of dike and pillow chilled margins recovered during DSDP Leg 83 are presented. Chilled margins of pillows exhibit a maximum of four textural zones. From the margin inward these are (1) glass, (2) glass with isolated spherulites, (3) coalesced spherulites, and (4) plumose clinopyroxene coalesced with plagioclase in sheaf textures. Chilled margins of dikes exhibit a maximum of six zones that include from the margin inward (1) glass, (2) a cryptocrystalline texture ranging from equigranular (a) to porphyrotopic (b), (3) open spheruloids to radial-rim spheruloids in a cryptocrystalline matrix, (4) coalesced radial-rim spheruloids, (5) coalesced spherical to bowtie spherulites, and (6) plagioclase sheafs with interstitial plumose clinopyroxene. The sequence of zones occurring in a given dike margin is dependent on the nature of the contact with the country rock. Zones 1, 2a, 3, 4, and 5 are observed only in dikes in which the boundary with the country rock is irregular or convolute; in planar or subplanar dike/host contacts Zones 1, 2a, 3, 4 , and 5 are absent and replaced by Zone $2 \mathrm{~b}$. Zone 6 occurs in both margin types.

Although both dike and pillow margins demonstrate textures indicative of significant deviations from the equilibrium crystallization temperature and a progressive decrease in undercooling away from the margin, pillow margins formed under greater degrees of undercooling with higher cooling rates than dike contacts. In contrast, in dike chilled margins the undercooling and cooling rate are such that the nucleation density far surpasses that in pillow margins. The resulting textural features can be used to ascertain the mode of origin in incompletely recovered units.
\end{abstract}

\section{INTRODUCTION}

Current models of the structure of the oceanic crust are based primarily upon a combination of geophysical data (Orcutt et al., 1976; Houtz and Ewing, 1976), studies of ophiolite complexes (Pallister and Hopson, 1981; Dewey and Kidd, 1977; Cann, 1974; Moores and Vine, 1971), and petrologic studies of samples either cored or dredged from the ocean crust (Bryan and Moore, 1977). Verification of the models by means of drilling into the ocean crust has not been possible because average penetration of basement rock has been less than $600 \mathrm{~m}$. Thus, only samples of the pillow lavas and flows of Layer 2A have been recovered in situ. The basement penetration of $1076 \mathrm{~m}$ in Hole 504B during DSDP Leg 83 nearly doubled this average penetration. Study of material from layers deeper than Layer $2 \mathrm{~A}$, specifically, the transition zone and sheeted dikes of Layers $2 \mathrm{~B}$ and $2 \mathrm{C}$, is now possible. This demands an accurate recognition of dikes as opposed to pillow lavas or flows so that the location or depth to the transition between subsequent layers can be assessed.

Horizontal limitations of studying a 6-cm diameter core and vertical limitations of an average of $20 \%$ or less recovery frequently makes the visualization of threedimensional aspects of lithologic units obscure. Petrographically, dike and pillow chilled margins exhibit distinctly different sequences of textures with distance from the margin. These characteristics were applied to rapidly cooled samples from Hole 504B to ascertain whether rocks

\footnotetext{
${ }^{1}$ Anderson, R. N., Honnorez, J., Becker, K., et al., Init. Repts. DSDP, 83: Washington (U.S. Govt. Printing Office).

2 Present address: NASA-JSC, Mail Code SN2, Houston, TX 77058.
}

obviously representing some type of chilled margins were emplaced as dikes or as pillows where actual contacts were not recovered intact.

The purpose of this paper is twofold: (1) to describe the petrography of unequivocal pillow and dike chilled margins to facilitate their recognition in less completely recovered units and (2) to assess the differences in cooling histories or conditions that are responsible for the differences in textures observed between these two modes of emplacement.

\section{PETROLOGY AND GEOCHEMISTRY OF LEG 83 BASALTS}

Hole 504B is located $201 \mathrm{~km}$ south of the Costa Rica Rift in 5.9 m.y. old crust. The petrology and geochemistry of the basalts from Hole 504B have been studied in detail for the upper $561.5 \mathrm{~m}$ of the basement by Autio and Rhodes (1983) and the remaining $514 \mathrm{~m}$ by Kempton et al. (this volume). The results of these studies indicate that although the lavas are high in $\mathrm{MgO}$, they are low in incompatible trace elements, REE, and $\mathrm{Ti}$ in comparison to other mid-ocean ridge basalts (MORB). In addition, 1-atm. crystallization experiments indicate that the lavas are nearly saturated with plagioclase, olivine, and clinopyroxene at low pressures. On the basis of these data, the lavas have been interpreted as being evolved compositions, that is, they have suffered significant fractional crystallization, but were derived from a source previously depleted of much of its incompatible element content.

Most of the basalts are sparsely porphyritic. Plagioclase is the most abundant phenocryst phase $(5 \%$ or less). Olivine (now pseudomorphed by smectite and talc) is the second most abundant phenocryst phase (less than 
$1 \%$ ) with clinopyroxene only occasionally forming crystals of phenocryst proportions. Euhedral Cr-spinels occur in trace abundances, commonly associated with olivine and plagioclase phenocrysts. Many units, however, are aphyric. Groundmass textures range from fine grained, intergranular to coarse subophitic. Typically, the aphyric units exhibit the best developed subophitic textures. They are also the coarsest grained samples in the suite.

The basalts have been hydrothermally altered to varying degrees throughout the hole. As a result, olivine is completely altered to one or more phyllosilicates in most units. Plagioclase, although usually unaltered, has been partially replaced along cracks by laumontite, albite, or chlorite in some rocks. Augite is generally pristine, but in zones of intense alteration chlorite or actinolite occur along grain boundaries.

The pillow and dike margin features that will be described in the following sections are based on petrographic observations of 10 pillow margins and 15 dike margins. In addition, because many of the fine-grained textures encountered in these samples could not be resolved petrographically, backscattered electron imaging (BEI) of 1 pillow margin and 2 dike margins was performed. Samples studied are listed in Table 1.

\section{TECHNIQUES}

Microprobe analyses were performed on a JEOL electron microprobe at Southern Methodist University using mineral standards at $15 \mathrm{kV}$ accelerating potential and a $20 \mathrm{nA}$ sample current using 3 wavelength dispersive spectrometers. Raw data were processed on a PDP 11 to correct for dead time, background, and absorption, fluorescence, and atomic number (ZAF) using the alpha correction for oxides procedure developed by Bence and Albee (1968). Secondary electron imaging and backscattered electron imaging (BEI) were performed on the same instrument at low sample currents (2-4 nA) using standard polished thin sections.

Backscattered electrons are beam electrons that change direction and escape through the surface of the sample at high angles. The probability of this scattering is dependent on the mean atomic number or density of the sample such that low density phases, which provide a greater mean free path to the electron beam, produce few backscattered electrons. In a higher density phase, considerable scattering close to the surface is possible and a large fraction of incoming electrons are backscattered producing a brighter image. Backscattered electron images

Table 1. Samples examined, Hole 504B.

\begin{tabular}{lclc}
\hline $\begin{array}{c}\text { Pillow samples } \\
\text { (interval in cm) }\end{array}$ & $\begin{array}{c}\text { Phenocryst } \\
\text { phases }\end{array}$ & $\begin{array}{c}\text { Dike samples } \\
\text { (interval in cm) }\end{array}$ & $\begin{array}{c}\text { Phenocryst } \\
\text { phases }\end{array}$ \\
\hline $71-1,112-116^{\mathrm{a}}$ & OPC & $72-1,71-75$ & OPC \\
$72-1,19-23^{\mathrm{b}}$ & OP & $78-2,32-36^{\mathrm{a}}$ & OPC \\
$80-4,5-7^{\mathrm{a}}$ & OPC & $81-1,87-89$ & OP \\
$81-1,82-86^{\mathrm{a}}$ & OP & $92-2,43-47^{\mathrm{a}}$ & OPC \\
$82-2,72-76^{\mathrm{a}}$ & OPC & $93-1,64-68^{\mathrm{a}}$ & OPC \\
$82-2,75-79^{\mathrm{a}}$ & OPC & $99-2,17-21^{\mathrm{a}}$ & A \\
$82-3,3-7^{\mathrm{a}}$ & OPC & $100-2,74-77^{\mathrm{b}}$ & OPC \\
$84-2,104-108^{\mathrm{a}}$ & OPC & $101-1,76-79^{\mathrm{b}}$ & OPC \\
$86-1,9-13^{\mathrm{a}}$ & OPC & $103-1,9-13^{\mathrm{a}}$ & A \\
$90-1,132-136^{\mathrm{a}}$ & $\mathrm{P}$ & $107-1,11-15^{\mathrm{a}}$ & A \\
& & $111-1,84-86$ & OPC \\
& & $116-1,126-128^{\mathrm{a}}$ & OPC \\
& & $123-1,140-143$ & A \\
& & $129-3,30-36$ & OPC \\
& & $139-1,12-15$ & OPC \\
\hline
\end{tabular}

Note: $\mathrm{O}=$ olivine; $\mathrm{P}=$ plagioclase; $\mathrm{C}=$ clinopyroxene; $\mathrm{A}=$ aphyric.

a Samples available for shipboard observation only.

b Samples analyzed by SEI and BEI. can, therefore, be used as maps of the distribution and morphologies of phases too small to be resolved optically. However, it must be recognized that mineral phases may have overlapping average atomic weights or densities and, thus, be indistinguishable or unidentifiable in BEI (Hall and Lloyd, 1981).

\section{PREVIOUS WORK}

The distinctive textural features of pillow margins were described by Bryan (1972) for samples of lavas from the Red Sea Rift and the Mid-Atlantic Ridge. Kirkpatrick (1978) documented similar features for ocean basalts recovered during DSDP Leg 46, Hole 396B. He was able to delineate six zones within a complete pillow margin that were defined on the basis of the appearance of phases combined with textural changes across the margin. He interpreted these changes as an indication of reducing cooling rate toward the interior of the pillow. Experimental corraboration of the interpreted cooling histories suggested by these textures has been almost nonexistent for actual ocean floor compositions (Lofgren and Donaldson, 1975). Textural features in Grande Ronde, Columbia River, pillow basalts have been experimentally reproduced by Schiffman and Lofgren (1982). In their experiments, cooling rates of $2400^{\circ} \mathrm{C} / \mathrm{hr}$ were required to reproduce the vitrophyric rims of the pillows and $10^{\circ} \mathrm{C} / \mathrm{hr}$ to imitate the holocrystalline interiors. In addition, extensive programmed crystallization studies have been made on lunar basalts (Lofgren, 1975; Donaldson et al., 1975; Walker et al., 1976; Dowty et al., 1974). Application of these experimental results permits at least qualitative estimates of cooling rate and histories for terrestrial rocks of similar compositions. An excellent review of experiments on crystallization of silicate melts can be found in Lofgren (1980).

Petrographic descriptions and experimental studies of dike chilled margins have been largely neglected. Early attempts to quantify the kinetics of nucleation and growth based on the numbers of crystals and changes in crystal size with distance from the margin were made by Lane (1898) and extended by Gray $(1970,1978)$. In a more theoretical approach to the kinetic problem, Kirkpatrick (1976) employed computer modeling techniques in the crystallization of a hypothetical 2-m-wide dike. His work estimates that the first centimeter of the dike crystallizes within the first few hours after injection. The dike should completely crystallize within 2 to 3 days. Kirkpatrick's model also predicts that both nucleation and growth rates decrease significantly toward the dike interior. Petrographic descriptions of changes in crystal morphologies and the implications with respect to undercooling and cooling rate have not been discussed.

\section{PILLOW TEXTURES IN LEG 83 BASALTS}

Chilled margins of pillows recovered in Hole 504B exhibit a maximum of four distinct zones. From the margin inward these are (1) glass, (2) glass with isolated spherulites, (3) coalesced spherulites, and (4) plumose clinopyroxene coalesced with plagioclase in sheaf textures. The interior boundary of Zone 4 is gradational with the crystalline interior as grain size increases and skeletal crystal morphologies are replaced by faceted crystals. These zones are illustrated in Figures 1-5 and discussed in the text. 


\section{Zone 1}

The glassy zone was not recovered in all samples of pillow margins. Although it is believed to have been present in all pillows originally, a combination of secondary alteration and the brittle fracturing as a consequence of drilling probably contributed to its lack of recovery. When recovered, the thickness of the zone ranges from 1 to $4 \mathrm{~mm}$. The glass is commonly brecciated or fractured into triangular or polygonal shapes. In pristine samples the glass is black in hand specimen and has an amber color in thin section, but is dark gray to grayish green in the more altered samples. The subsequent alteration has a concentric habit that parallels the polygon boundaries.

Euhedral phenocrysts of plagioclase and olivine are generally present, and occasionally rounded clinopyroxene xenocrysts occur as well. Plagioclase phenocrysts are $2-5 \mathrm{~mm}$ in size, and glomerocrystic aggregates are common. Olivines are generally less than $1 \mathrm{~mm}$ in size, but phenocrysts up to $2 \mathrm{~mm}$ occur. Spherulitic or dendritic overgrowths were not observed.

\section{Zone 2}

This zone, present in most recovered pillow margins, ranges from 2.5 to $5 \mathrm{~mm}$ in width. It consists of small, circular- or oval-shaped, dark brown spherulites 100 $300 \mu \mathrm{m}$ in size set in a matrix of glass (Fig. 1A). Plagioclase microlites $100-200 \mu \mathrm{m}$ in size, as well as the plagioclase phenocrysts, have acicular to dendritic extensions arising from the corners of the laths that are enveloped by the same dark brown spherulitic growth. Backscattered electron imaging (BEI) of the spherulites indicates that although plagioclase microlites occur in the cores, the spherulites are not composed exclusively of plagioclase (Fig. 1B). Rather, they are intergrowths of at least three phases arranged as elongate radial fibers extending outward from the central microlite. Texturally similar spherulites in pillow lavas from DSDP Leg 46 were termed plagioclase spherulites by Kirkpatrick (1978). However, BEI of these spherulites indicates that they are identical to those from Leg 83 (Figs. 2A, 2B). It cannot be unequivocally established at the present level of analysis whether all of the phases of plagioclase, clinopyroxene, olivine, and glass are included in these intergrowths, but petrographic and BEI observations combined with broad-beam microprobe analyses indicate that clinopyroxene and glass, not plagioclase, constitute the majority of the encircling spherulites.

\section{Zone 3}

Zone 3 is distinguished from Zone 2 on the basis of two coincident features: (1) a polygonal rather than circular outline of the spherulites resulting from their coalescence during growth and (2) the appearance of pale brown (in plane polarized light) spherulites in addition to the dark brown spherulites (Fig. 3A). The spherulites in Zone 3 are slightly larger than those in Zone 2, up to $0.55 \mathrm{~mm}$ in diameter. BEI indicates that the dark brown varioles are identical to those in Zone 2, having a radial arrangement of clinopyroxene \pm plagioclase, olivine, and glass surrounding the plagioclase microlite cores (Fig. 3B). The light brown varioles, however, originated as dendritic olivine (now altered to phyllosilicates) plus an intergrowth of clinopyroxene and glass (?) in the interstitial areas between the dendritic branches (Fig. 3C). Skeletal plagioclase microlites (up to $0.5 \mathrm{~mm}$ in length) are common in the cores of the dark brown spherulites; mi-
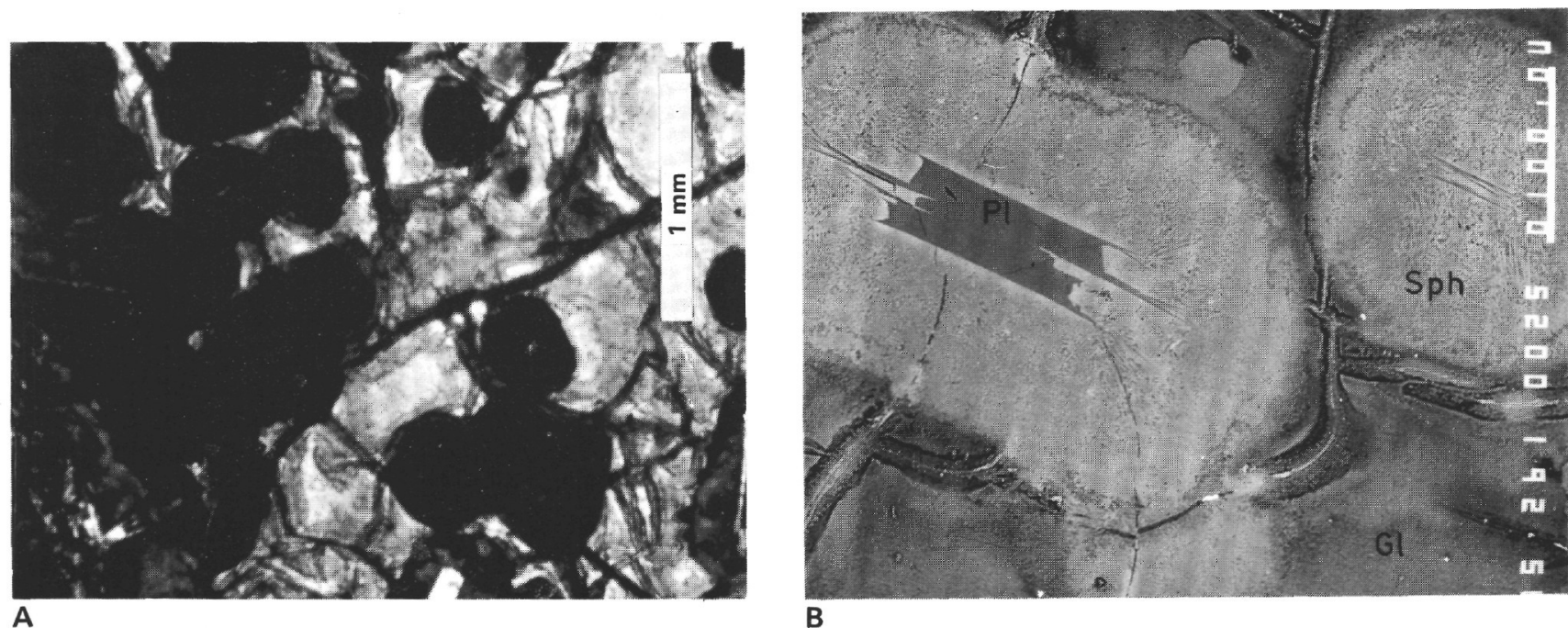

A

Figure 1. Pillow margin Zone 2 in Sample 504B-72-1, 19-21 cm. (A) Isolated dark brown spherulites in a glass matrix. Transmitted light photomicrograph. (B) Backscattered electron image (BEI) of dark brown clinopyroxene spherulites demonstrating that the spherulitic overgrowths are not composed predominantly of plagioclase, but rather clinopyroxene. Note the dendritic breakdown of plagioclase at the crystal corners. Phases are identified in BEI as follows: clinopyroxene = light gray, glass (?) = medium gray, plagioclase = dark gray, and secondary phyllosilicates = black. The sequence of numbers printed along the right margin in this photo and in all subsequent BEI photographs correspond to the following information. From bottom to top: accelerating voltage (e.g, $15 \mathrm{kV})$, magnification $\left(261=26 \times 10^{1}\right)$, photo sequence number $(0025=25$ th photo taken $)$, scale including scale bar and length in microns. $\mathrm{Pl}=$ plagioclase, Gl $=$ glass, Sph $=$ polyphase spherulitic overgrowth, comprised predominantly of clinopyroxene. 


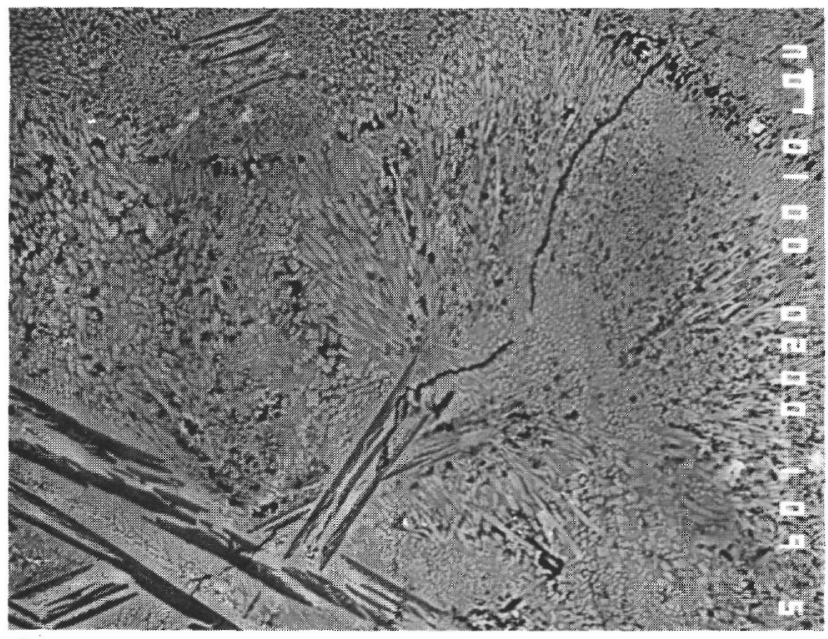

A

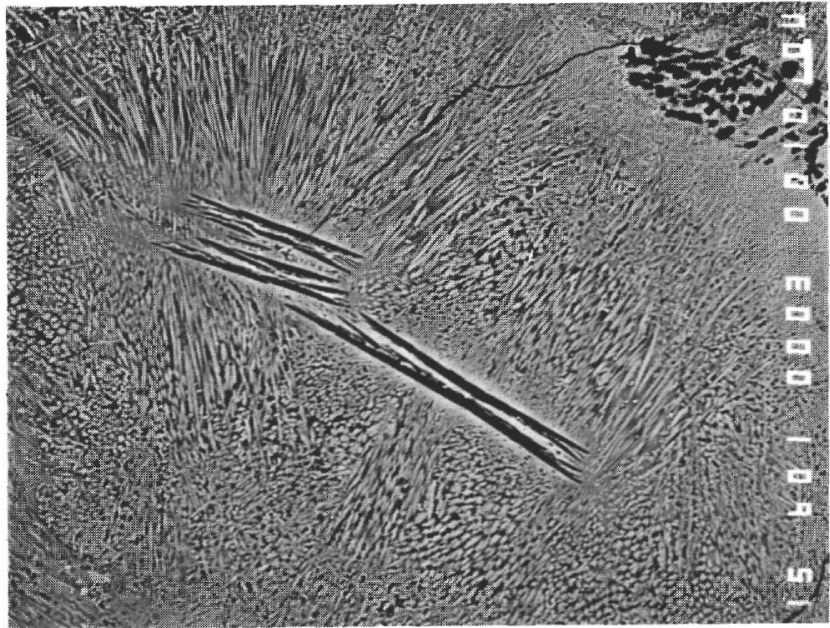

B

Figure 2. Pillow margin Zone 3. (A) BEI photo of dark brown clinopyroxene spherulite in Sample 504B-72-1, 19-21 cm. Crystallization of clinopyroxene encompasses the skeletal plagioclase microlite. (B) BEI photo of dark brown clinopyroxene spherulites from Hole $396 \mathrm{~B}$, Leg 46. Phases present are the same as in Sample 504B-72-1, 19-21 cm.

crophenocrysts occurring either alone or in clusters of two or three crystals have either the same dark brown fibrous overgrowth or form the nucleus of several locally coalesced olivine dendrite spherulites.

In samples where clinopyroxene is modally abundant, a third textural type of spherulite appears abruptly at the interior margin of Zone 3 with Zone 4 . The varioles have elongate or oval shapes and have extinction patterns that are not strictly radial, but rather sweep in small segments. They are pale brown in plane polarized light, similar to the olivine dendrite spherulites, but in crossed polars they exhibit distinctly higher observable birefringence (Figs. 4A, B). Tabular to skeletal plagioclase microlites with acicular extensions elongate parallel to the feldspar (010) crystal face occupy the cores of the varioles (Fig. 4C). Clinopyroxene, which has nucleated along the length of these microlites, grows as elongate crystals at high angles to the plagioclase surface (Figs. 4B, C). The remainder of the spherulite is a composite of clinopyroxene and a second phase of lower average atomic weight, possibly glass. Broad-beam microprobe analyses indicate that this intergrowth is compositionally similar to that composing the dark brown varioles, but with possibly less glass.

Although each variole type is actually a composite of several phases, to facilitate further discussion each shall be referred to on the basis of its predominant phase or distinguishing feature. Light brown varioles with low birefringence composed of olivine dendrites plus interstitial clinopyroxene and glass will be referred to as olivine dendrite spherulites. Light brown varioles with moderate birefringence composed predominantly of clinopyroxene will be called light brown clinopyroxene spherulites. Dark brown varioles consisting of an intergrowth of clinopyroxene, glass \pm plagioclase, and olivine will be termed dark brown clinopyroxene spherulites.

Euhedral olivine phenocrysts and microphenocrysts $0.2-2.5 \mathrm{~mm}$ in size are present in Zone 3. FeTi-oxides are generally too small to recognize optically in this zone. BEI verifies that they occur as small crystals less than $1 \mu \mathrm{m}$ in size lining the variole boundaries. If clinopyroxene spherulites are abundant, oxides greater than $1 \mu \mathrm{m}$ are more abundant.

In fresh samples, Zone 3 is dark gray to black in hand specimen; in altered samples, however, this zone has a very pale, greenish color.

\section{Zone 4}

The transition from Zone 3 to Zone 4 is gradational in terms of size and abundance of the light brown clinopyroxene spherulites, but relatively abrupt with respect to the disappearance of the olivine dendrite spherulites and dark brown clinopyroxene spherulites. At the boundary with Zone 4, the relative area occupied by the light brown clinopyroxene spherulites reaches a maximum; nearer the interior the clinopyroxene morphology gradually changes from variolitic to interstitial immature plumose textures (Fig. 5A). Plagioclase abruptly loses the dark brown fibrous overgrowths and appears as slightly larger (up to $0.45 \mathrm{~mm}$ in length) coarse, axiolitic spherulites (Fig. 5B). These resemble bundles of plagioclase aciculae elongate parallel to the $(010)$ crystal face. The individual needles of the spherulites are separated by clinopyroxene that has crystallized along the plagioclase laths and grown perpendicular to its surface (Fig. 5C). Skeletal or tabular microphenocrysts as well as microlites possess these acicular extensions. They form the interiors of many of the light brown clinopyroxene varioles, but also occur separate from them.

Nearer the pillow interior, plagioclase increases in size and abundance and the axiolitic spherulites enlarge to form crystals with sheaf textures up to $0.8 \mathrm{~mm}$ in length; clinopyroxene occurs between the plagioclase sheafs as plumose crystals. With increasing distance from the margin, plagioclase sheafs coalesce, and clinopyroxene is restricted to an interstitial occurrence as larger plumose crystals than before (Figs. 5D, E).

FeTi-oxides occur as equant crystals less than $5 \mu \mathrm{m}$ in size lining the boundaries of coalesced clinopyroxene spherulites. Oxides also appear intergrown with the cli- 


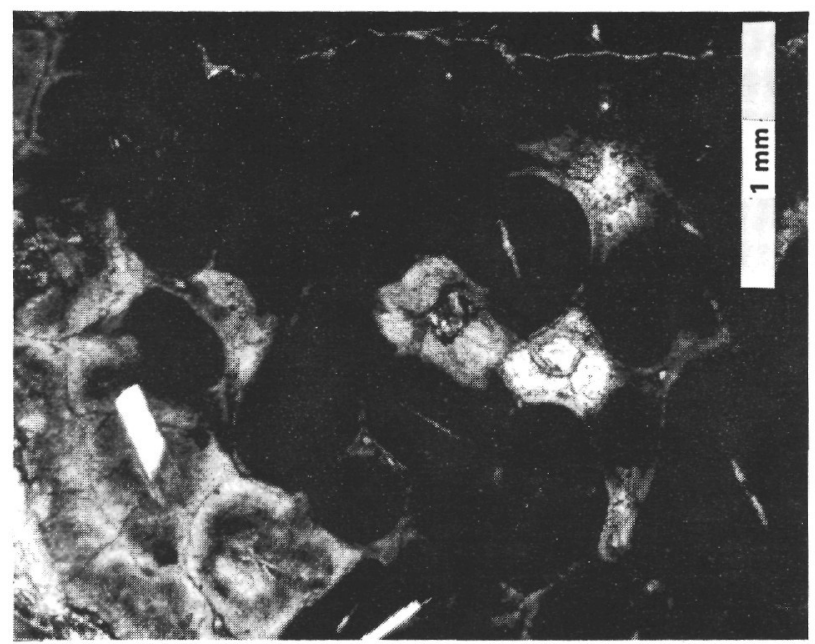

A

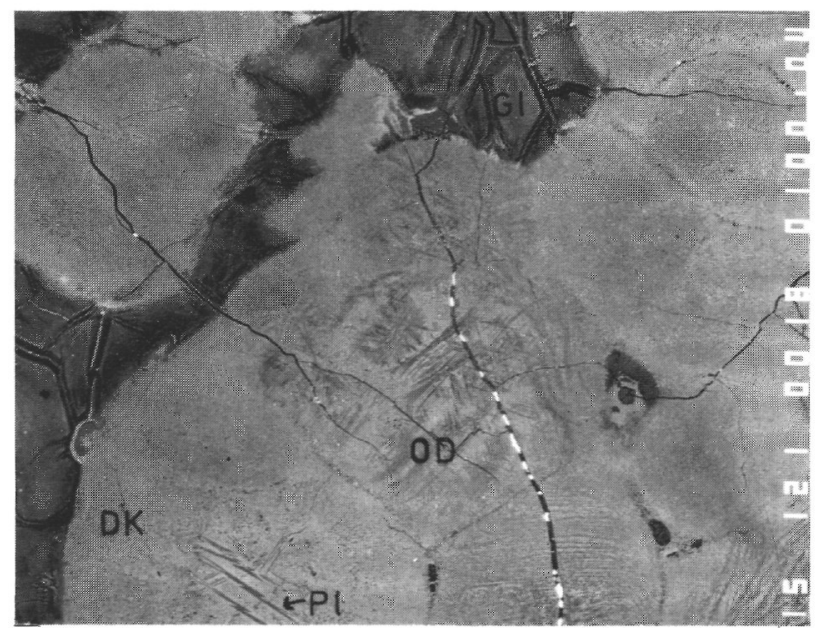

B

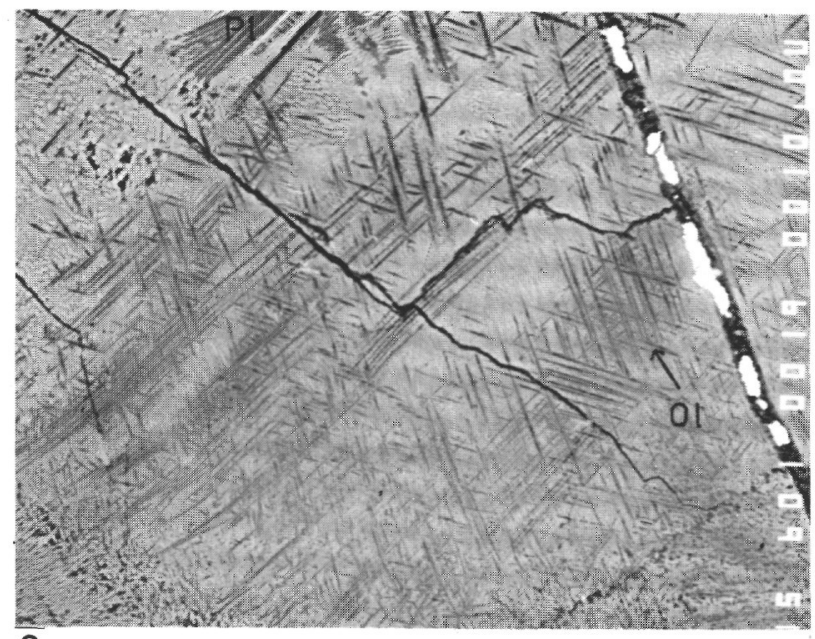

C

Figure 3. Pillow margin Zone 3 in Sample 504B-72-1, 19-21 cm. (A) Coalesced dark brown clinopyroxene spherulites and olivine dendrite spherulites. Plagioclase microlites are present in the cores of both spherulite types. Transmitted light. (B) BEI photo of coalesced spherulites. DK $=$ dark brown clinopyroxene spherulites, $\mathrm{OD}=$ olivine dendrite spherulites, $\mathrm{Gl}=$ glass, $\mathrm{Pl}=$ plagioclase (C) Higher magnification of olivine dendrite spherulite. Olivine is now altered to phyllosilicates and occurs as the dark, cross-hatched phase marked as 01 on the photo. The remainder of the spherulite is an intimate intergrowth of clinopyroxene, glass (?) \pm plagioclase.
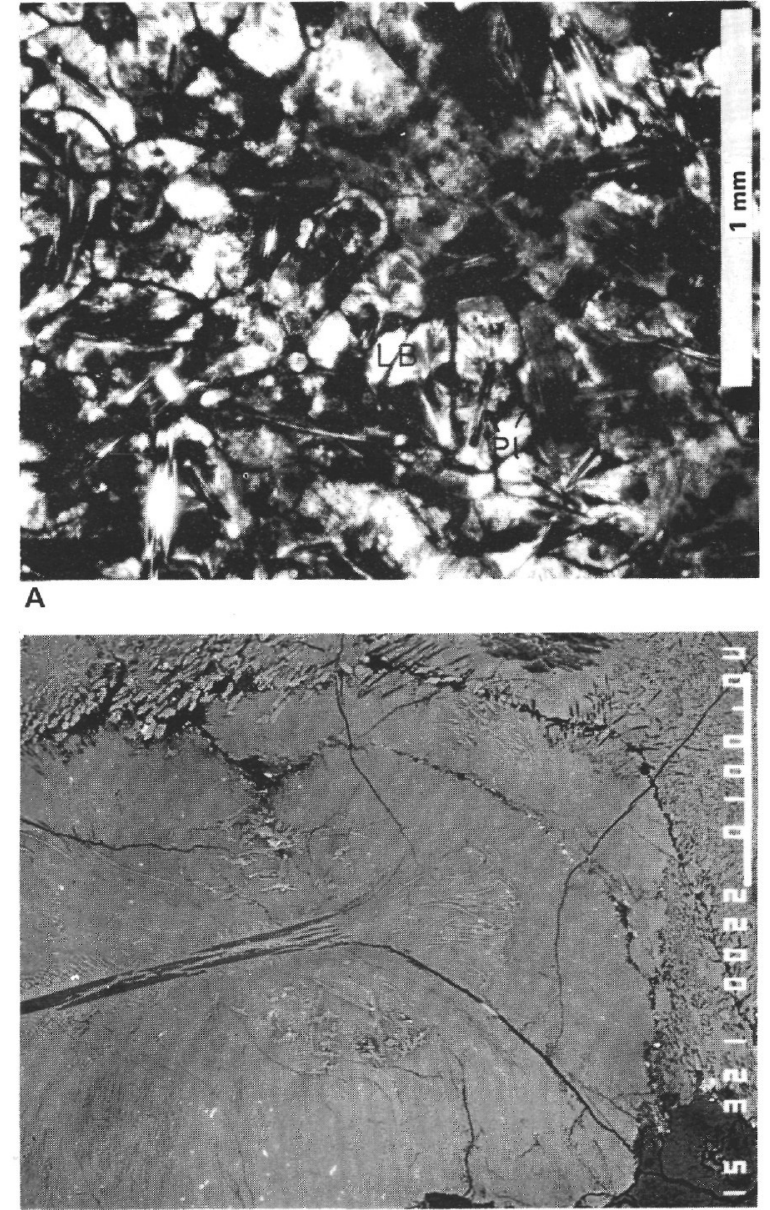

B

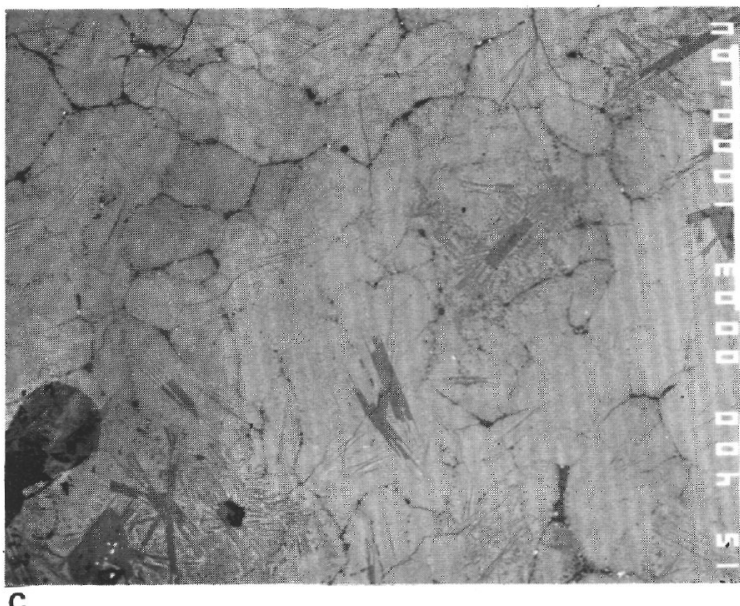

C

Figure 4. Pillow margin Zone 3 in Sample 504B-72-1, 19-21 cm. (A) Coalesced light brown clinopyroxene spherulites. Plagioclase occurs as axiolitic spherulites enveloped by clinopyroxene and as more sheaflike textures when not surrounded by the clinopyroxene spherulites. Transmitted light. LB = light brown clinopyroxene spherulites, $\mathrm{Pl}=$ plagioclase. (B) BEI photo of a light brown clinopyroxene spherulite. Clinopyroxene alone initially nucleated and grew perpendicular to the plagioclase surface. The surrounding spherulitic growth is a composite of clinopyroxene and an additional unidentified phase, but its mineralogy is more homogeneous than the dark brown spherulites. Clinopyroxene is light gray, plagioclase is intermediate gray, alteration is black, FeTi-oxides are white. (C) BEI photo of coalesced light brown clinopyroxene spherulites. Note FeTi-oxides lining the boundaries between adjacent spherulites. 

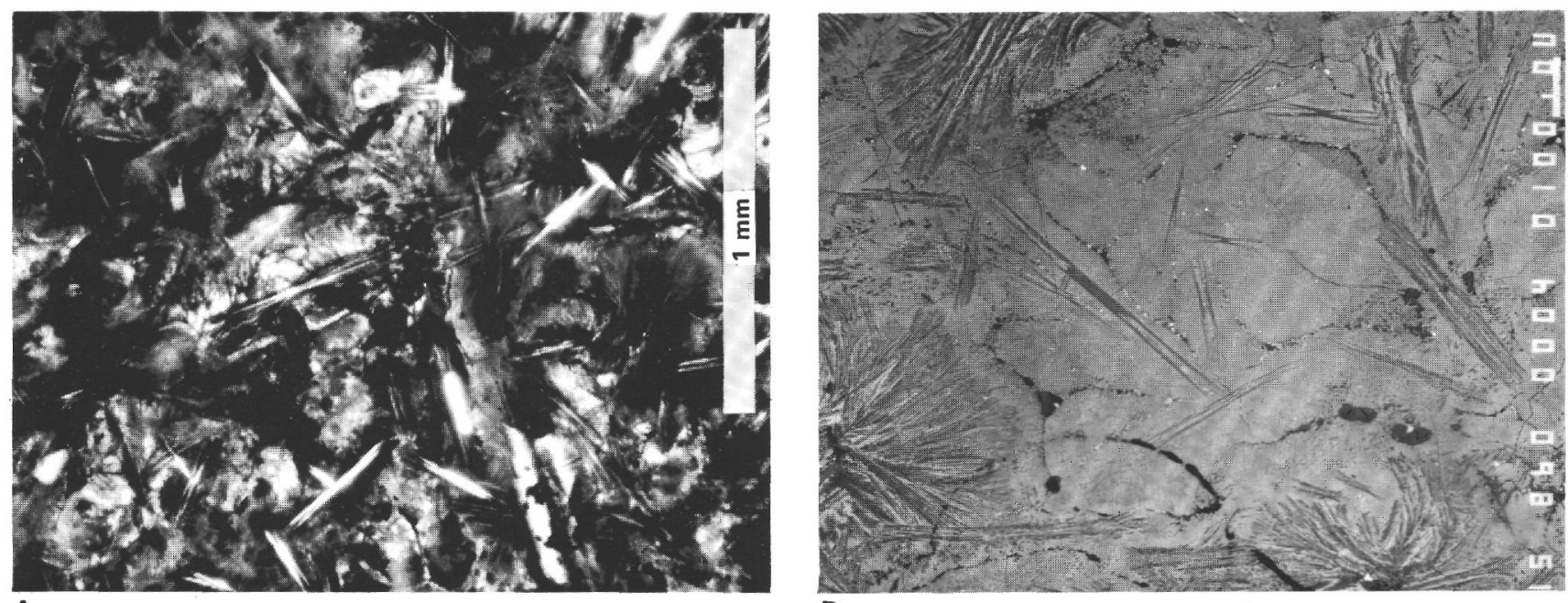

A

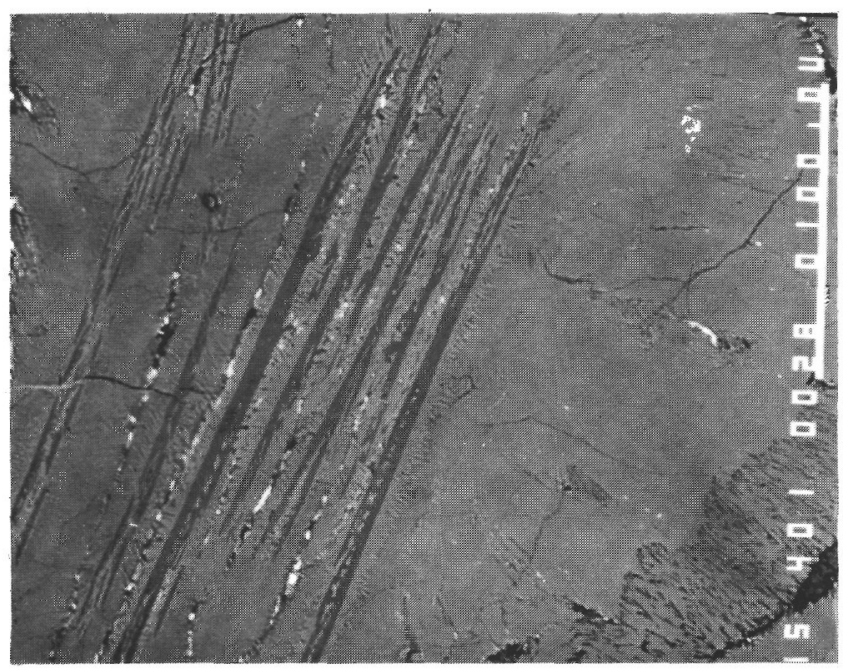

C

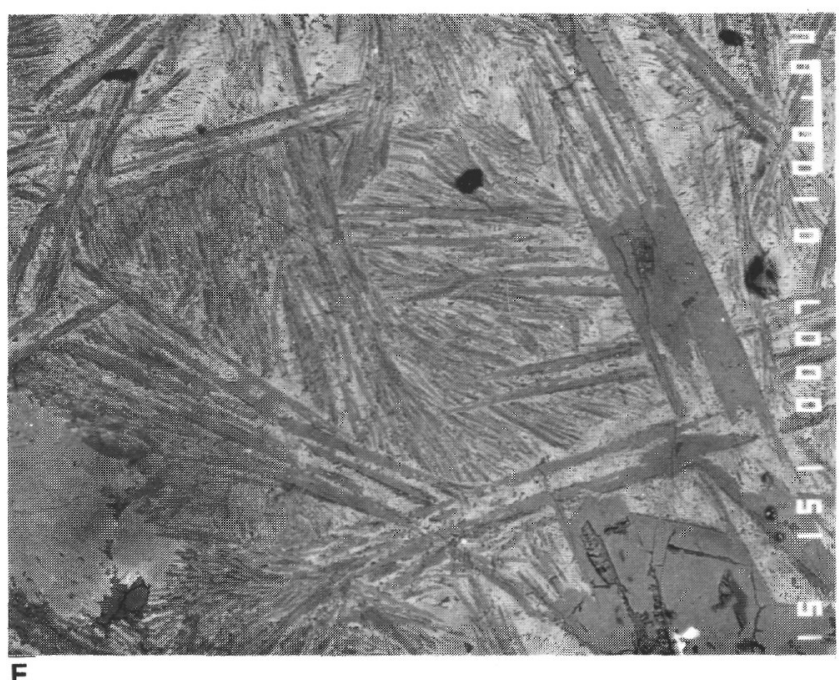

\section{B}
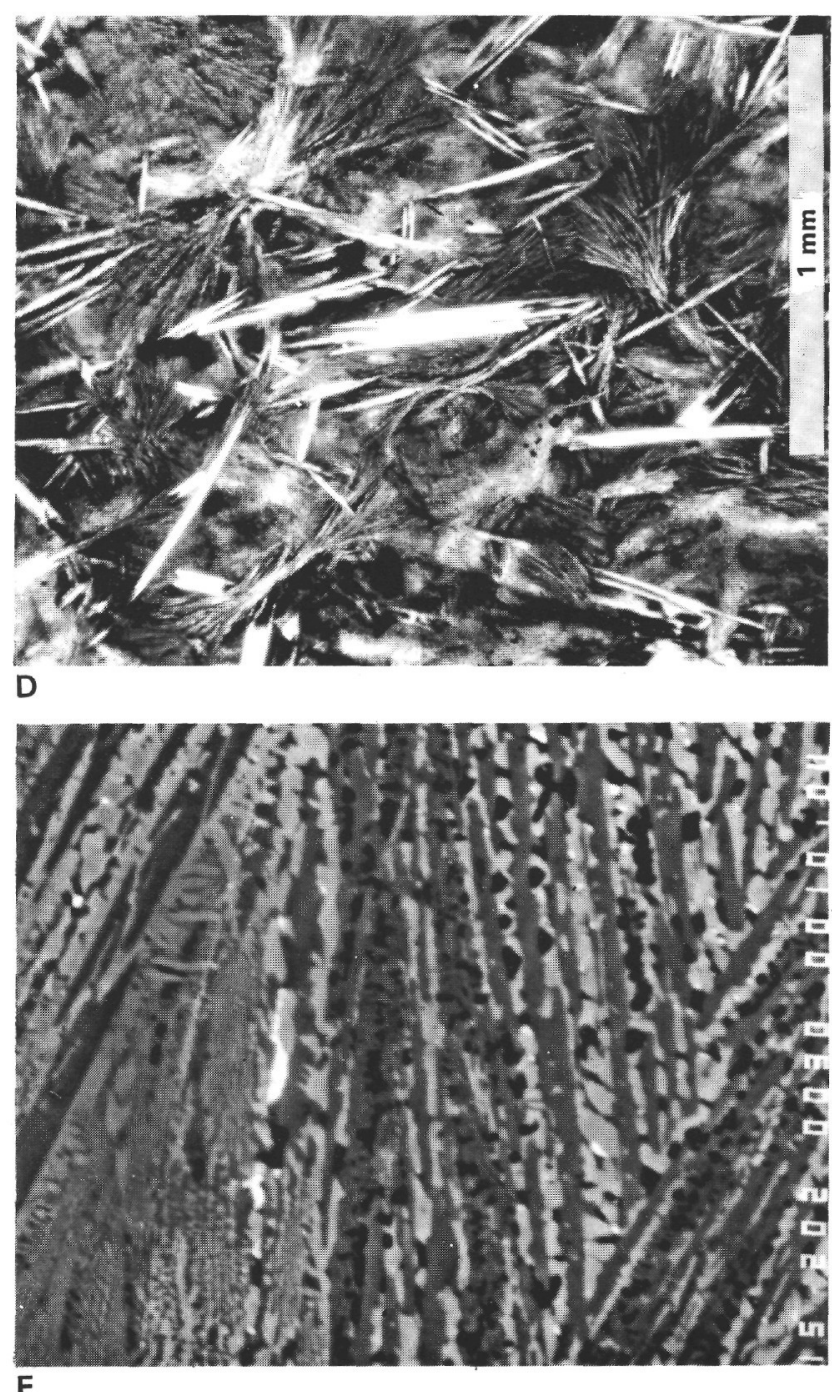

$\mathbf{F}$

Figure 5. Pillow margin Zone 4 in Sample 504B-72-1, 19-21 cm. (A) Portion of Zone 4 adjacent to Zone 3. Plagioclase textures range from axiolitic spherulites to sheaves; clinopyroxene ranges from spherulitic to interstitial plumose textures. Transmitted light. (B) BEI photo of the same portion of Zone 4 shown in Figure 5A. (C) BEI photo of axiolitic plagioclase. Note the concentration of clinopyroxene and FeTioxides between the plagioclase aciculae surrounded by a clinopyroxene intergrowth spherulite. (D) Plagioclase sheaves plus interstitial plumose clinopyroxene. Transmitted light. (E) BEI photo of a similar portion of Zone 4 shown in Figure 5D. Note the skeletal plagioclase laths extending into sheaf textures; clinopyroxene occurs as plumose crystals restricted to the interstitial volumes between plagioclase aciculae. (F) Higher magnification BEI photo of plagioclase sheaf intergrown with clinopyroxene and FeTi-oxides. 
nopyroxene that nucleated on the plagioclase aciculae of the axiolitic spherulites.

The interior boundary of Zone 4 is believed to be gradational with a microlitic interior. This cannot be documented, however, since a physically continuous sequence from pillow margin to interior was not recovered during Leg 83. Therefore, the width of Zone 4 is unknown; it must be a minimum of $1-2 \mathrm{~cm}$. Based on textural variations within fragments of the same unit, it is apparent that toward the interior of the pillow the elongate plagioclase microlites and microphenocrysts become less sheaflike and gradually increase in size. Clinopyroxene changes from plumose textures to subophitic or intergranular. In the plumose textures subparallel crystals of clinopyroxene nucleated along the length of the plagioclase laths and grew as radiate sprays that have a sweeping extinction pattern along the spray. The entire spray may be up to $100 \mu \mathrm{m}$ wide and the individual crystals of the plumes $5-10 \mu \mathrm{m}$. Intergranular to subophitic textures in which clinopyroxene possesses a more equant morphology occur in the pillow interior. Euhedral pseudomorphs of olivine phenocrysts occur, but olivine is neither abundant as a phenocryst phase nor in the groundmass.

\section{DIKE MARGINS}

Structurally and texturally dike and pillow margins exhibit several characteristics that distinguish them. Dike margins are intrusive contacts against a host material. This intrusive margin is generally planar to subplanar, but may be brecciated or highly contorted (Fig. 6). Microlites and small phenocrysts are nearly always preferentially aligned parallel to the contact. Disaggregated polycrystalline fragments of the host wall rock are common in the dike margins (Fig. 7A). In cases where the host/dike boundary is sharp or planar, phenocrysts and groundmass crystals in the wall rock are truncated (Fig. 7B). Furthermore, the sequence of crystal morphologies and groundmass textures observed from margin to interior of dikes is markedly different from that documented for pillow chilled margins.

Six dike-margin zones have been recognized in samples from Hole 504B. These zones are defined predominantly based on changes in crystal morphology and distribution of phases. From the margin inward these zones include (1) glass, (2) cryptocrystalline texture ranging from equigranular (a) to porphyrotopic (b), (3) open spheruloids to radial-rim spheruloids set in a cryptocrystalline matrix, (4) coalesced radial-rim spheruloids, (5) coalesced spherical spherulites to bowtie spherulites, and (6) plagioclase sheaves with interstitial plumose clinopyroxene.

The sequence of textural zones is not always completely developed in a given dike margin and is related to the nature of the host/dike contact. Zones 1, 2a, 3, 4, and 5 are observed only in dikes in which the boundary with the host is irregular or convolute; in planar or subplanar dike/host margins, Zones 1, 2a, 3, 4, and 5 are absent and replaced by Zone $2 \mathrm{~b}$. Zone 6 occurs in both margin types, succeeding Zone 4 in the irregular margins and Zone $2 \mathrm{~b}$ in sharp or planar margins.
In general, the textural sequence observed in both dike and pillow margins indicates trends of decreasing cooling rate and undercooling from the margin to the interior. In dike margins, however, significantly lower average values for these parameters are implied by the greater degree of crystallinity combined with the lesser development of spherulitic or dendritic crystal morphologies. These textural features are illustrated in Figures 8-10 and discussed in the text.

\section{Zone 1}

Zone 1 is rarely developed in dike margins recovered from Hole 504B. In fact, only one sample, 504B-123-1, $140-143 \mathrm{~cm}$, was recovered in which glass was identified at an intrusive margin (Fig. 6B). The contact is highly convoluted and the glass now altered to phyllosilicates. The zone is variable in width ranging from 1 to $4 \mathrm{~mm}$ along the contact. Polycrystalline fragments plucked from the wall rock are observed to be in various states of disaggregation throughout the margin. As in the pillow margins, phenocrysts and microphenocrysts show no evidence of quench crystallization at their rims. The typical absence of this zone strongly indicates that cooling conditions are seldom appropriate for complete quenching of magma to $100 \%$ glass along these dike margins.

\section{Zone 2}

Zone 2 is the zone most commonly adjacent to the wall rock. Because crystal sizes are too small to be resolved petrographically, this zone is referred to as cryptocrystalline (Fig. 8). BEI shows that Zone 2 is composed of an intimate intergrowth of three or four phases including plagioclase and clinopyroxene \pm olivine (now altered to smectite) and FeTi-oxides. In samples having irregular or convoluted contacts, the cryptocrystalline border is typically equigranular; all phases are approximately the same size $(2-4 \mu \mathrm{m})$, and crystal morphologies are equant, predominately anhedral (Figs. 9A, B). Microphenocrysts and phenocrysts are subhedral to euhedral and possess no spherulitic or dendritic overgrowth.

In samples where the boundaries between host and dike are sharp or planar, a greater range in crystal sizes and morphologies is observed. The term porphyrotopic has been adopted to describe this texture. (The term was originally suggested to describe the fabric of a chemically precipitated sedimentary rock in which the constituent crystals were of more than one size and in which larger crystals were enclosed in a fine-grained matrix; Friedman, 1965.) Grain sizes in porphyrotopic dike margins range from less than $1 \mu \mathrm{m}$ to approximately $15 \mu \mathrm{m}$. Aside from the distinctly larger plagioclase microphenocrysts, larger grain sizes are not restricted to any one phase. Although most crystals are anhedral, larger plagioclase crystals are subhedral, having more tabular shapes. Spherulitic overgrowths are not present.

Equant FeTi-oxides (3-5 $\mu \mathrm{m}$ in size) occur commonly in the groundmass of the cryptocrystalline porphyrotopic borders, but were not positively identified in the equigranular zones. In samples studied, this zone ranges from 0.5 to $2.5 \mathrm{~mm}$ wide. 


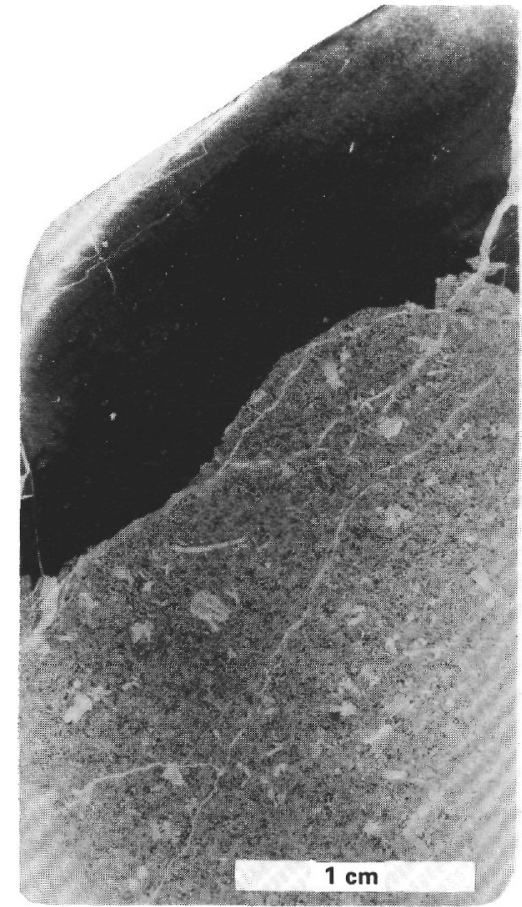

A

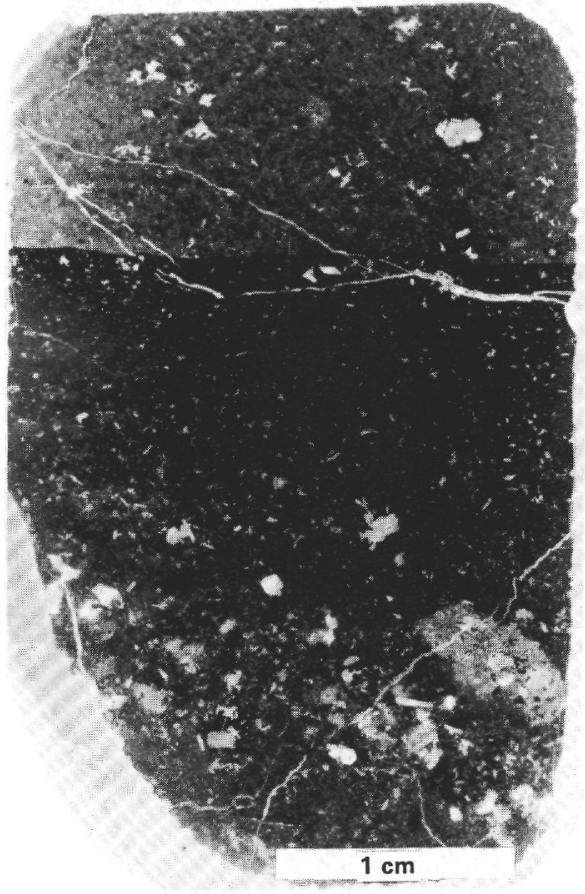

B

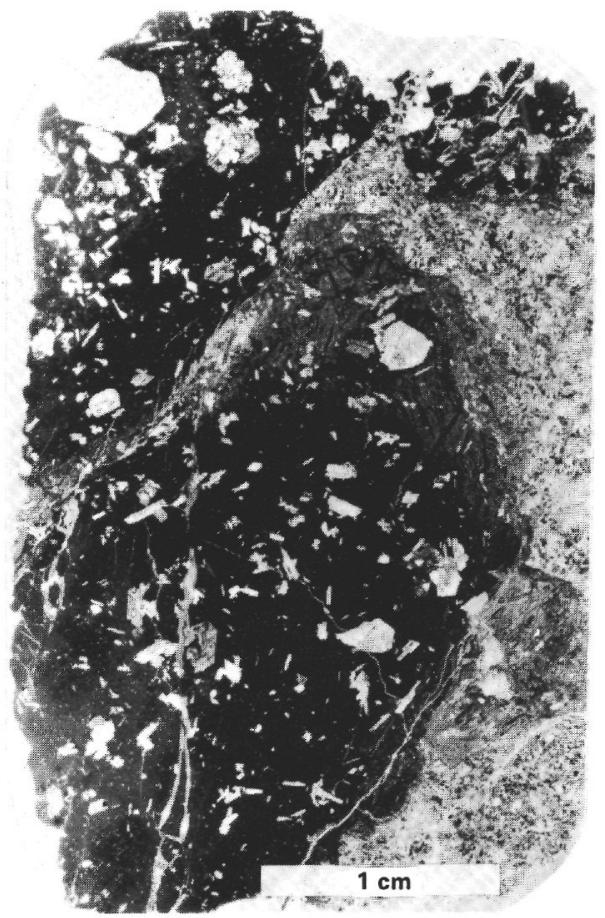

C
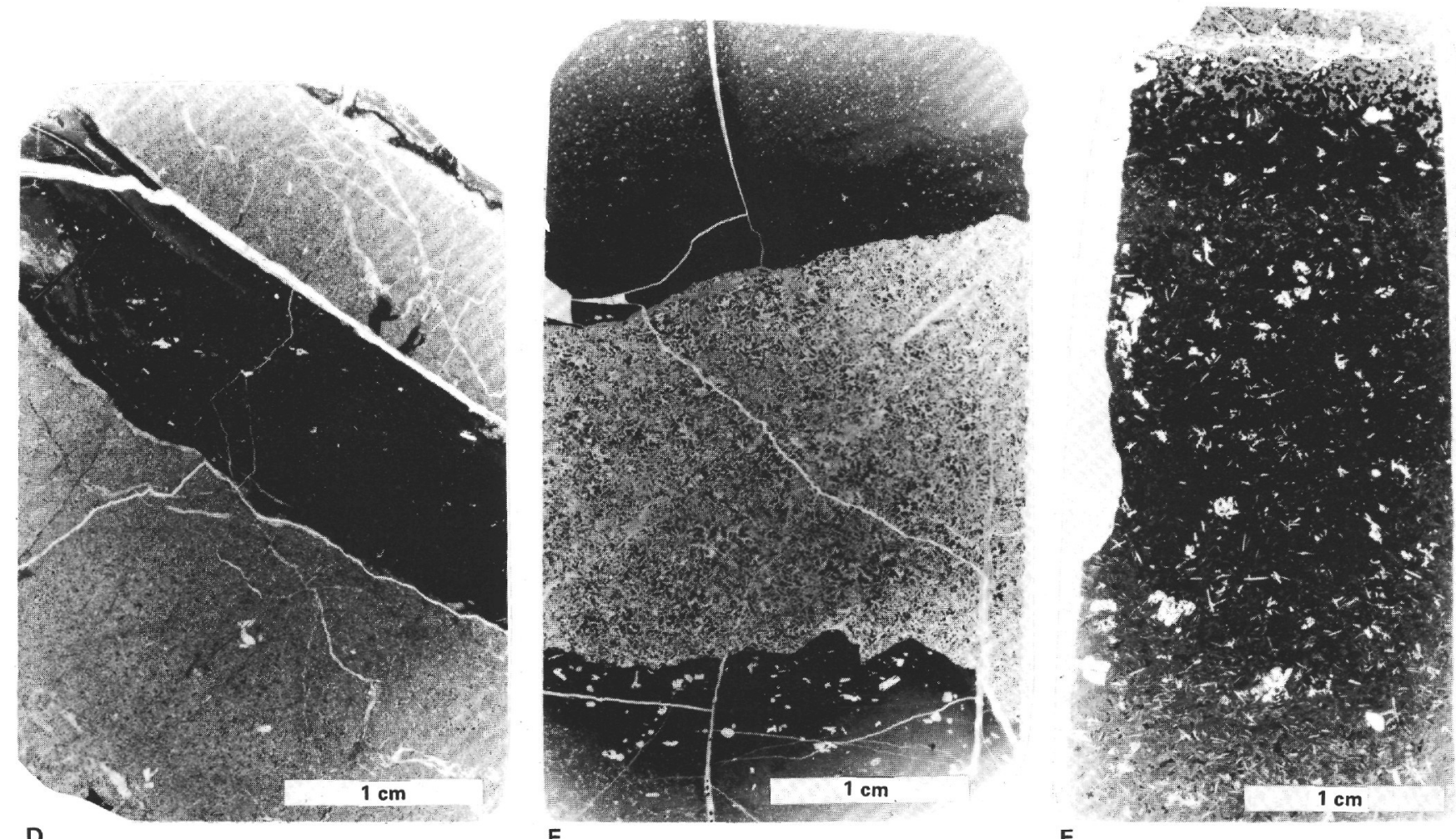

F

Figure 6. (A) Irregular dike margin. Sample 504B-100-2, 74-77 cm. (B) Planar dike margin. Sample 504B-101-1, 76-79 cm. (C) Convoluted dike margin. Sample 504B-123-1, 140-143 cm. (D) Irregular dike margin. Sample 504B-129-3, 30-36 cm. (E) Two irregular dike margins intruding the same host. Sample 504B-111-1, 84-86 cm. (F) Pillow margin. Sample 504B-72-1, 19-21 cm.

\section{Zone 3}

Zone 3 is defined by the appearance of spheruloid clusters $50-100 \mu \mathrm{m}$ in size set in a cryptocrystalline matrix (Fig. 9C). This zone has only been observed adjacent to the cryptocrystalline equigranular Zone 2a. Pet- rographically, the speruloids are observable as diffuse, light-colored spheres surrounded by a darker matrix (Fig. 8). Grain sizes are too small to determine the birefringence or extinction patterns. Although these clusters have a spherical to subspherical shape, they are referred to as spheruloids because they do not possess the 

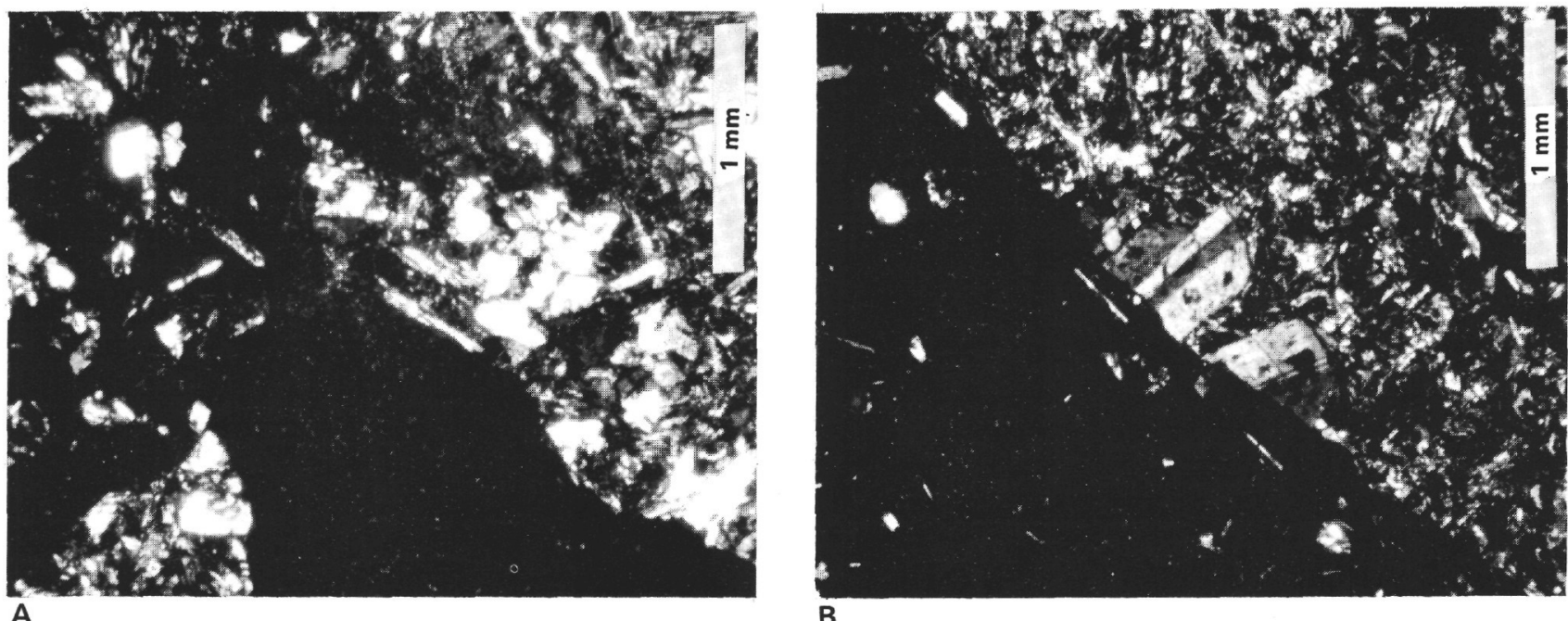

B

Figure 7. (A) Disaggregated wall rock fragments in irregular dike margin. Sample 504B-116-1, 126-128 cm. Transmitted light. (B) Truncated plagioclase phenocrysts in wall rock adjacent to planar dike margin. Sample 504B-101-1, 76-79 cm. Crossed polars.

radial orientations of elongate crystals implicit in the definition of spherulite. BEI inspection of these clusters shows that they are polyphase aggregates of equigranular crystals, the individual crystals of which are less than $3 \mu \mathrm{m}$ in size (Figs. 9C, D). Plagioclase and clinopyroxene are the major constituent phases although plagioclase predominates. In common with the spherical spherulites observed in pillow margins, one or more plagioclase crystals frequently occupy the cores of these spheruloids. These crystallites are commonly too small to be distinguished petrographically (less than $40 \mu \mathrm{m}$ ). They are more elongate and develop acicular extentions as the interior boundary of this zone is approached. Clinopyroxene frequently occurs in greater abundance adjacent to the plagioclase cores than elsewhere in the spheruloid. Outward from this core, the two major phases, plagioclase and clinopyroxene, are intimately intergrown in nearly constant modal proportions. Although the matrix in which the spheruloids occur is comprised of the same mineral phases, an increase in modal clinopyroxene serves to define the boundaries of the clusters (Fig. 9D). This average crystal size changes only slightly from Zone 2 to Zone 3, coarsening toward the interior of the dike, and the spheruloids adjacent to Zone 2 do not change appreciably in crystal size from core to rim. However, adjacent to Zone 4 the spheruloids take on a subtle radiate appearance in which larger, more elongate crystals extend outward from the homogeneously distributed, equant crystals of the spheruloid center (Fig. 9E). This is manifested petrographically as lighter colored, more birefringent spheruloids. These radial-rim spheruloids have more distinct boundaries and exhibit an imperfect radial extinction pattern in thin section.

\section{Zone 4}

Zone 4 is distinguished from Zone 3 by the coalescence of the spheruloid clusters. However, unlike the polygonal shapes that result from the coalesced spherical spherulites in pillow margins, the boundaries of the spheruloid clusters become diffuse. The gradational character of this transition frequently makes the boundary between Zones 3 and 4 difficult to recognize by normal petrographic techniques (Fig. 8). The spheruloids are somewhat larger than in Zone 3, ranging from 100 to 150 $\mu \mathrm{m}$. Spheruloids increase in size across the zone toward the interior margin. Plagioclase crystals in the cores of these spheruloids are larger than in Zone $3(30-60 \mu \mathrm{m})$; they occur as tabular microlites with acicular extensions elongate parallel to the (010) crystal face (Fig. 9F). Clinopyroxene nucleation appears to have been initially concentrated around these plagioclase microlite cores. Clinopyroxene forms elongate crystals perpendicular to the surface of the feldspar and encompasses most of the surface area of the microlites. As in Zone 3, equant, homogeneously distributed crystals of plagioclase and clinopyroxene surround the core microlites; the rims, however, consist of an intergrowth of elongate clinopyroxene and plagioclase \pm olivine aciculae arranged in a radial fashion about the homogeneous center (Fig. 9F). Near the boundary with Zone 5 the relative abundance of olivine increases in the rim portion of the spheruloids. The spheruloids exhibit a concentrically zoned appearance consisting of light-colored cores and darker rims (Fig. 8), due to the typical alteration of olivine to phyllosilicates. As in Zone 3, clinopyroxene is concentrated in the interstitial volumes between adjacent spheruloids. In thin section these appear as irregularly shaped, yellow-brown patches with moderate birefringence. FeTioxides are small, equant crystals randomly distributed throughout. The width of this zone ranges from 0.5 to $2.5 \mathrm{~mm}$ for the samples studied.

\section{Zone 5}

Zone 5 is distinguished from the coalesced radial-rim spheruloids of Zone 4 by the development of a more complete radial arrangement of the constituent crystals such that they can justifiably be termed spherulites, (Figs. 9G, H). The first spherulitic bodies to develop are intergrowths of plagioclase, clinopyroxene, and olivine (now altered to clays). These spherulites are the largest 

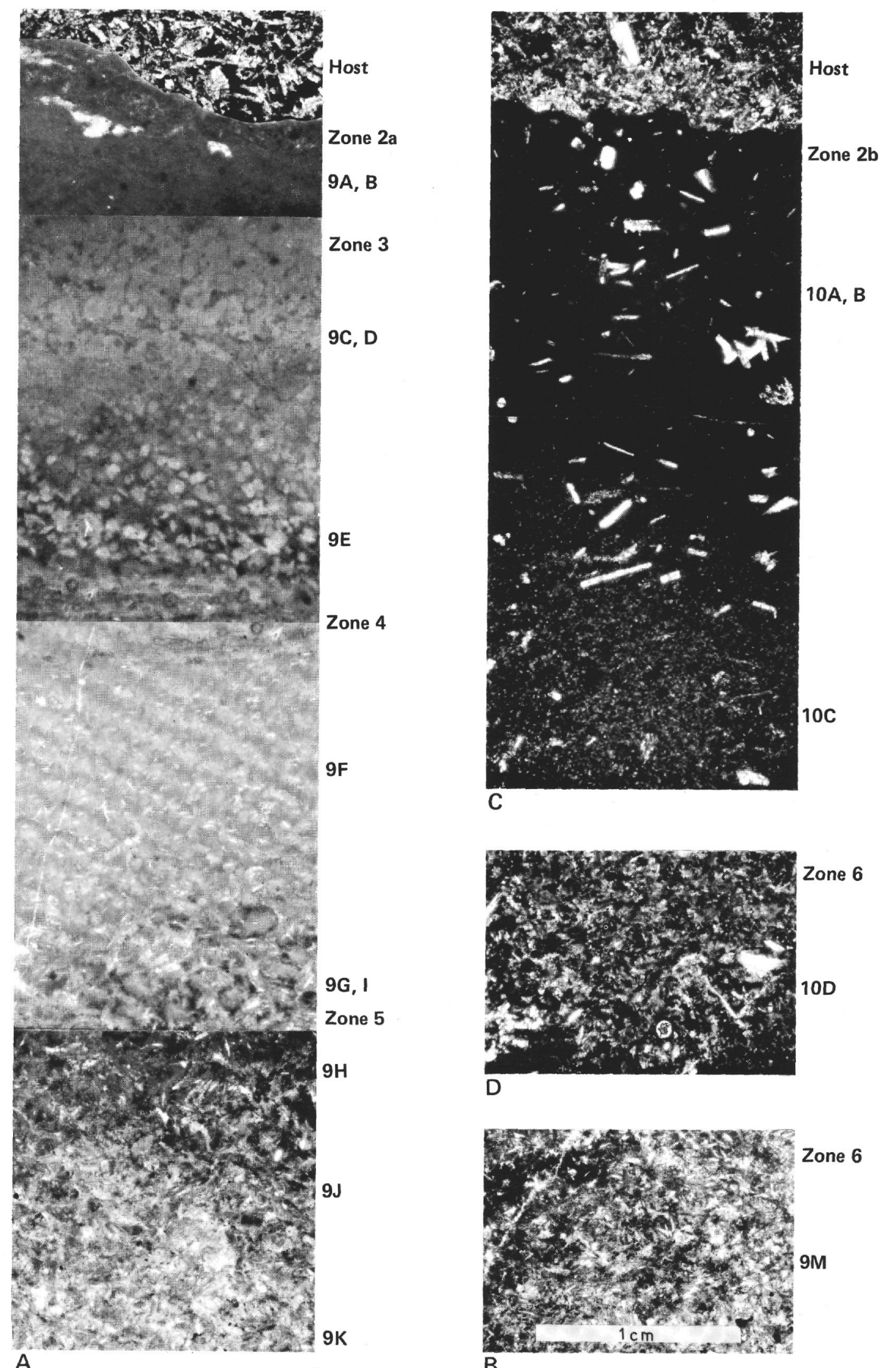

Figure 8. Composite low magnification photomicrograph of irregular and planar dike margins. Approximate location of corresponding BEI photo is indicated by figure number. Transmitted light. (A) Zones $2 a, 3,4$, and 5 in irregular dike margin. Sample 504B-100-2, 74-77 cm. (B) Zone 6 in irregular dike margin. Sample 504B-100-2, 74-77 cm. (C) Zone $2 \mathrm{~b}$ in planar dike margin. Sample 504B-101-1, 76-79 cm. (D) Zone 6 in planar dike margin. Sample 504B-101-1, $77-79 \mathrm{~cm}$. 
observed in the entire margin (up to $250 \mu \mathrm{m}$ ) and have spherical to subspherical shapes. The plagioclase microlites that occupy the centers of these spherulites range from 30 to $80 \mu \mathrm{m}$ in size and are essentially identical in appearance to the microlites occurring within the radialrim spheruloids. Clinopyroxene appears to have nucleated initially on the surface of the plagioclase. It subsequently grew perpendicular to the plagioclase surface as elongate crystals intergrown with plagioclase, olivine, and FeTi-oxides. The size of the crystals increases outward from the central plagioclase microlite as does the relative proportion of olivine (Fig. 9H). This textural arrangement produces concentrically zoned clusters. Coexisting with the spherical spherulites are coarse bowtie spherulites $100-200 \mu \mathrm{m}$ in size. They are composed predominately of plagioclase and clinopyroxene (Figs. 9I, J). In transmitted light they are light brown. The boundaries between adjacent spherulites appear diffuse as in the coalesced spheruloids of Zone 4 . Near the interior margin of this zone the boundaries of the bowtie spherulites are defined by relatively coarse-grained intergrowths of clinopyroxene, plagioclase, FeTi-oxides \pm olivine. Grain sizes on the order of tens of microns are in marked contrast to the less than $1-\mu \mathrm{m}$-wide needles comprising the spherulites (Fig. 9K). Extinction is imperfectly radial and sweeps outward along the spherulites into the coarse-grained areas suggesting that they are crystallographically contiguous. FeTi-oxides are distributed randomly throughout the spherulites, but are increasingly concentrated along the spherulite boundaries associated with the coarse-grained crystals with distance from the margin. This zone is $1-2 \mathrm{~mm}$ wide.

\section{Zone 6}

This zone occurs in dike margins with either irregular or planar host/dike margin, Figures 9L, M, and 10C. The textural changes result from continued coarsening of grain size similar to that observed in the coarse-grained areas between adjacent bowtie spherulites in Zone 5. Figures $9 \mathrm{~L}, \mathrm{M}$ demonstrate the way in which the spherulitic texture is gradually dominated by areas of coarse grain size. Although clinopyroxene continues to form irregularly shaped interstitial crystals, plagioclase tends to become increasingly more tabular. Eventually the texture consists of tabular plagioclase microlites with interstitial plumose clinopyroxene. The plagioclase microlite laths may be as much as $600 \mu \mathrm{m}$ long in porphyrotopic samples; they generally occur as mats of small microlites less than $50 \mu \mathrm{m}$ long in the equigranular margins. Olivine occurs as small euhedral crystals in the groundmass and as phenocrysts. FeTi-oxides are present as equant crystals less than $10 \mu \mathrm{m}$ in size that line the boundaries between adjacent plumose clinopyroxenes.

\section{THEORY}

The theories of nucleation and growth of crystals are reasonably complex and beyond the scope of this paper. However, the petrographic features observed in dike and pillow margins are attributable to differences in the nucleation and growth rates for the conditions each experienced. For this reason, a brief summary is warranted; the purpose is not a rigorous discourse of nucleation or growth theory, but rather to provide a frame of reference for the discussion to follow. More in-depth review of the processes, kinetics, and mathematical expressions of nucleation and growth are available in Kirkpatrick (1981, 1983), Dowty (1980), and Jackson (1977).

Nucleation is the process by which one phase forms initially in another. If this process takes place spontaneously, it is called homogeneous nucleation; if the nucleation is due to particulate or foreign matter within the parent material acting as a substrate for nucleation, the process occurs heterogeneously. Classical theories of nucleation have focused on homogeneous nucleation because several simplifying assumptions can be made that facilitate the mathematics. This theory will be summarized here.

Conceptually homogeneous nucleation occurs when small spontaneous variations in the character of the initial phase (in this case a melt) takes place such that atoms cluster together in the character of a new phase. However, a free-energy barrier exists to the formation of the new phase because the free energy of the small cluster of atoms is greater than the free energy of the same atoms in the melt; it is not until a critical size, $r^{*}$, of the cluster is reached that the free energy begins to decrease. The steady-state concentration of critical nuclei present can then be considered in terms of the probability that small clusters of atoms produced during random fluctuations in conditions within the melt will be stable and survive. The mathematical expression for this probability is a Boltzman distribution (Kirkpatrick, 1981):

$$
N_{r}^{*}=N_{\nu} \exp \left(-\Delta G^{*}{ }_{\text {tot }} / \mathrm{RT}\right)
$$

where $N_{v}$ is the number of atoms per volume in the reacting phase, $\mathrm{R}$ is the gas constant, $\mathrm{T}$ is absolute temperature, and $\Delta G^{*}$ the total or critical free energy of the critical cluster. The nucleation rate is a function of this equilibrium concentration of critical nuclei and the number of atoms in the reactant adjacent to the cluster surface, the probability that the atom has sufficient energy to overcome the energy barrier for attachment and the frequency of attempts of the individual atoms to overcome the energy barrier for attachment. An expression for this rate has the form (Kirkpatrick, 1981)

$$
I=n^{*} \nu_{v} \exp \left(-\Delta G_{a} / \mathrm{RT}\right) \exp \left(-\Delta G^{*} / \mathrm{RT}\right)
$$

where $n^{*}$ is the number of atoms in the reactant phase next to the critical nucleus, $\nu$ is the frequency with which an atom tries to overcome the free energy barrier, $\Delta G_{a}$ is the activation energy. $I$ has the units of nuclei/ $\mathrm{cm}^{3}$ of reactant phase/s.

However, this expression is derived for the steady-state nucleation rate. Some assumptions in its derivation are that the nucleation occurs randomly throughout the process, that there is no volume change upon crystallization, and that the crystals do not move (Kirkpatrick, 1976). For the natural system under consideration some of these assumptions are invalid. For example, magma is obviously not immobile during the entire nucleation 


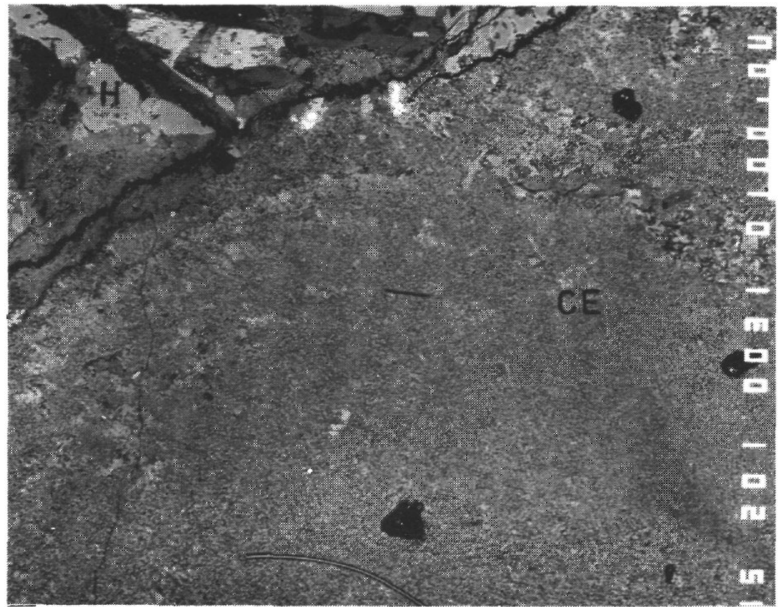

A

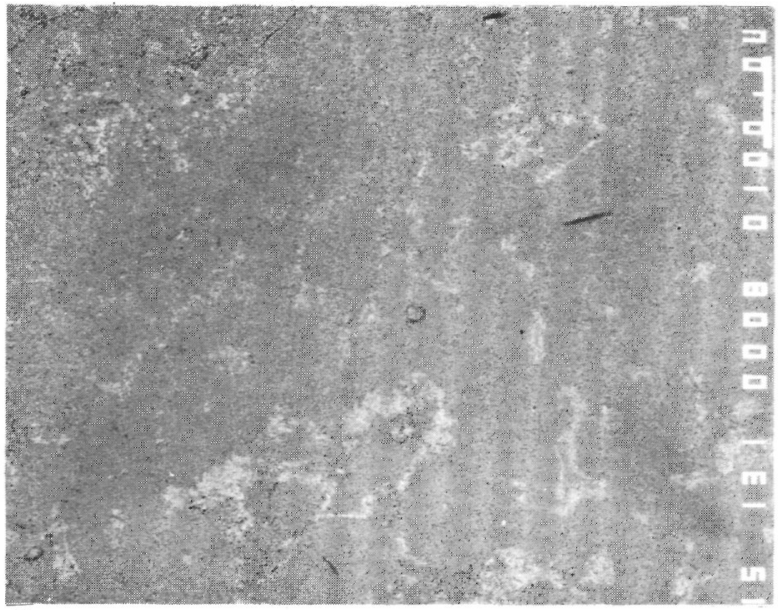

C

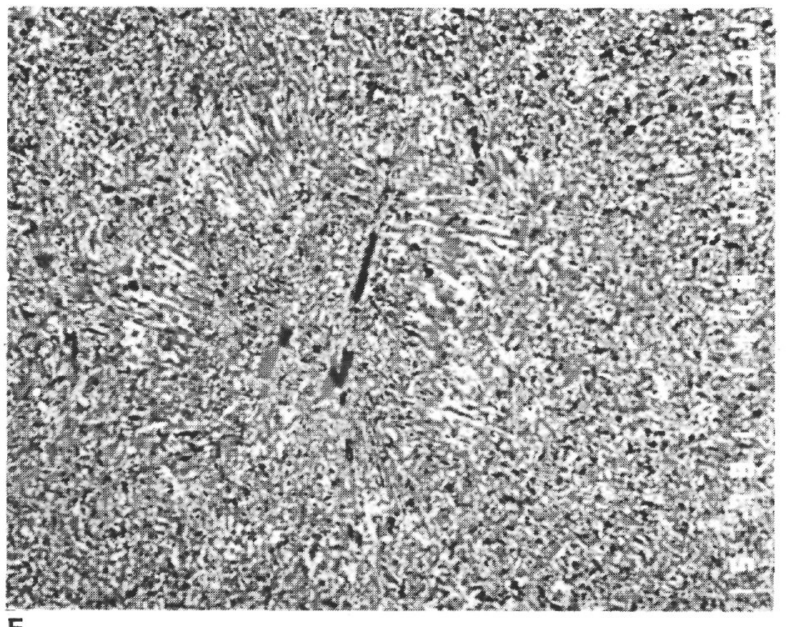

E

Figure 9. BEI photos of Zones 2a, 3, 4, 5, and 6 in irregular dike margin. Sample 504B-100-2, 74-76 cm. (A) Zone 2a, cryptocrystalline equigranular texture. Contact with the host wall rock occurs in the upper left. Phases are identified in BEI as follows: secondary alteration/phyllosilicates $=$ black, Ca-plagioclase $=$ medium gray, alteration of Ca-plagioclase (laumontite?) $=$ dark gray clinopyroxene $=$ light gray, secondary sulfide $=$ white, $\mathrm{H}=$ host, $\mathrm{CE}=$ cryptocrystalline equigranular Zone $2 \mathrm{a}$. (B) Zone 2a showing equigranular texture. Note lack of dendritic or spherulitic growth. (C) Zone 3 open spheruloids. Spheruloid boundaries are diffuse, outlined by patches of clinopyroxene (light gray). (D) Zone 3 spheruloid showing the lack of spherulitic or dendritic growth in these spherical clusters. Clinopyroxene is concentrated adjacent to plagioclase crystallites and along spheruloid boundaries. (E) Zone 3 radial-rim spheruloid showing the elongate radial arrangement of clinopyroxene and plagioclase at the spheruloid rim. (F) Zone 4 coalesced radial-rim spheruloids. Note the diffuse boundaries of the spheruloids. Plagioclase crystals have acicular extensions from the corners of the laths and are enveloped by crystallization of clinopyroxene. (G) Zone 5 spherical spherulites surrounded by bowtie spherulites. The spherical spherulites are composed of altered olivine (black), plagioclase (dark gray), clinopyroxene (light gray), and FeTi-oxides (white). Bowtie 


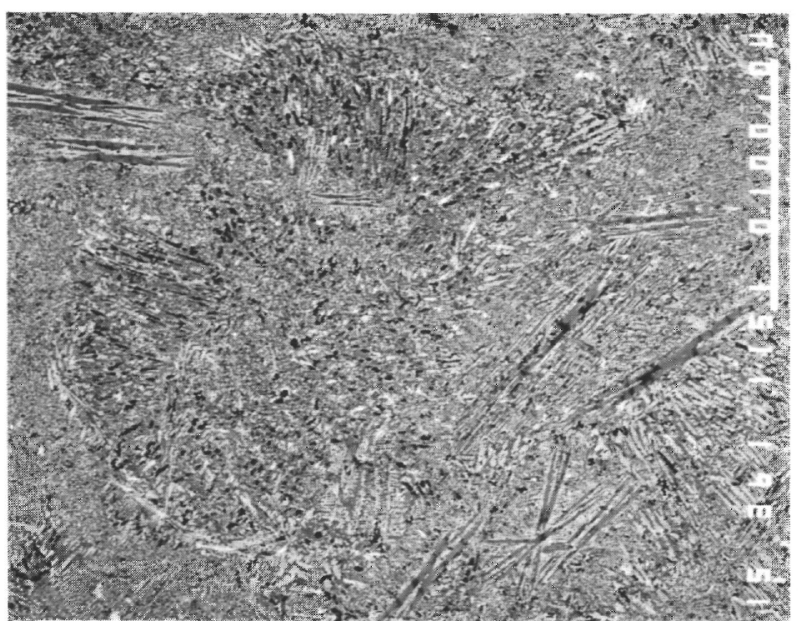

G

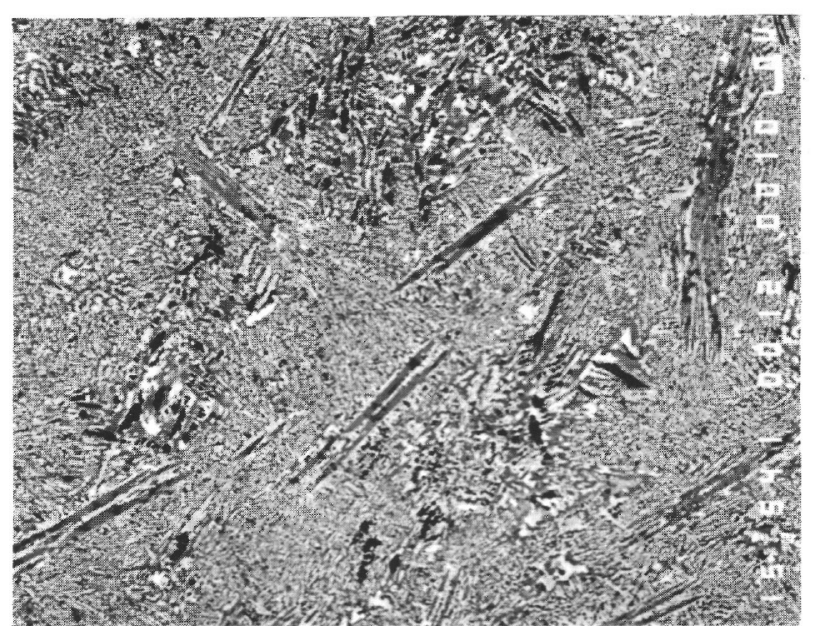

H

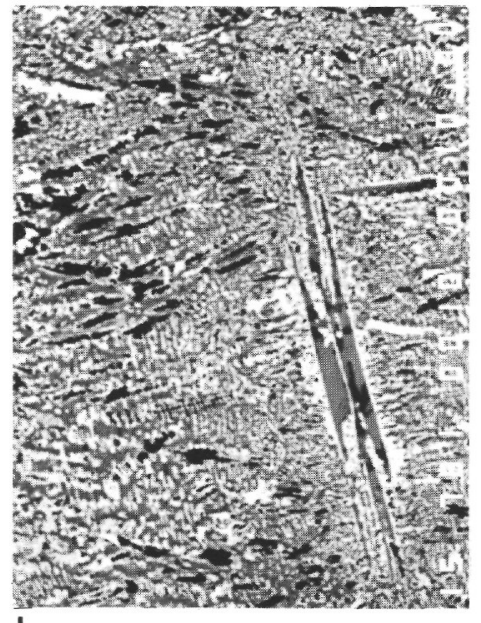

I

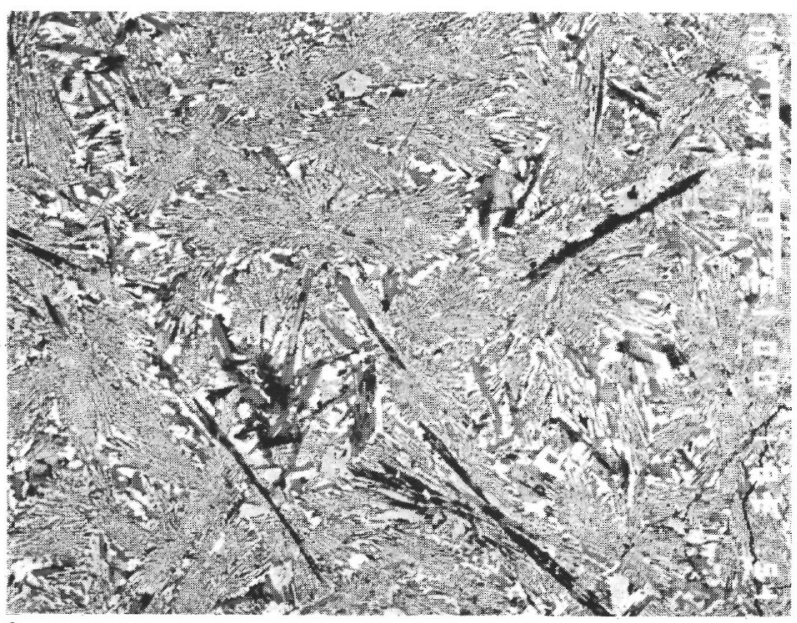
L

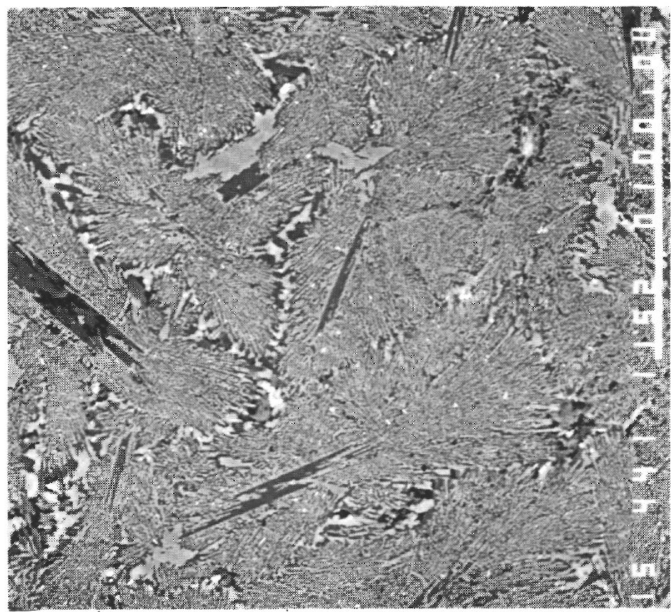

K

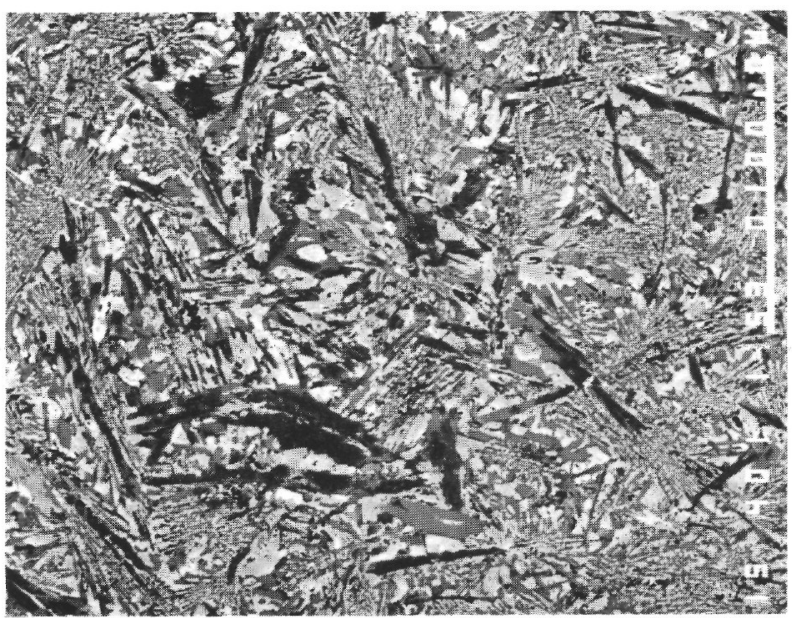

M

Figure 9. (Continued).

spherulites are composed predominantly of plagioclase and clinopyroxene. $(\mathrm{H})$ Zone 5 interior of Figure 9G. Note the increasing development of bowtie spherulites. Plagioclase occurs as elongate acicular crystals enveloped by clinopyroxene. (I) Higher magnification BEI photo of spherical spherulite. Clinopyroxene crystallization predominates adjacent to the skeletal plagioclase microlite core and is intergrown with olivine and plagioclase in a radial orientation away from the plagioclase surface. Note the increasing size of crystals and increasing concentration of olivine (now altered to phyllosilicates, black in BEI) outward from the center of the spherulite. (J) Zone 5 coalesced bowtie spherulites. (K) Zone 5 bowtie spherulites interior of Figure 9J. Borders of spherulites are recrystallized. Note tendency for FeTi-oxides to concentrate in the zones of coarse-grained crystals at spherulite boundaries. (L) Transition from Zone 5 to Zone 6. Coarse-grained areas are more extensive. Plagioclase is more tabular and clinopyroxene occurs as more equant crystals than in previous zones. (M) Zone 6 consisting of plagioclase is more tabular and clinopyroxene occurs as more equant crystals than in previous zones. Zone 6 consisting of plagioclase laths with interstitial plumose clinopyroxene and remnants of bowtie spherulites. 


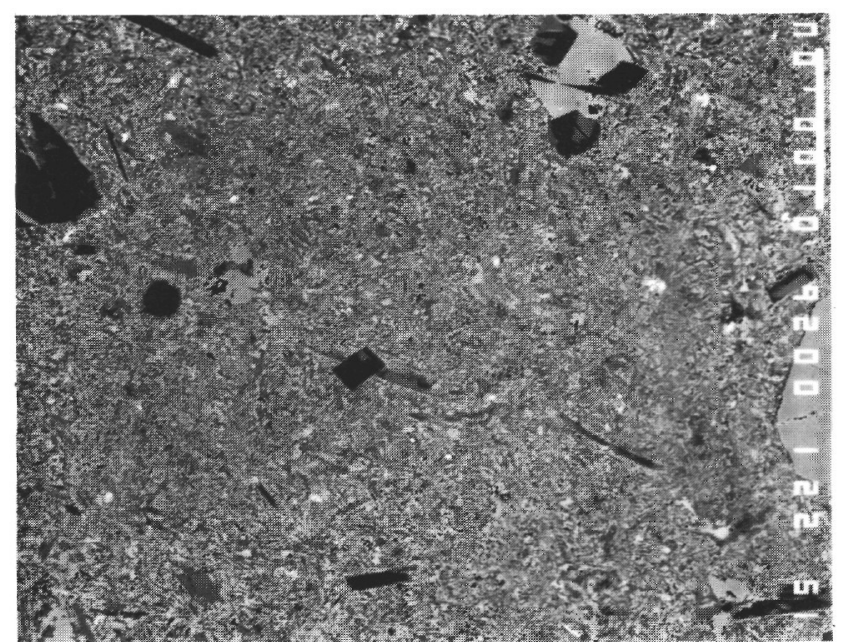

A

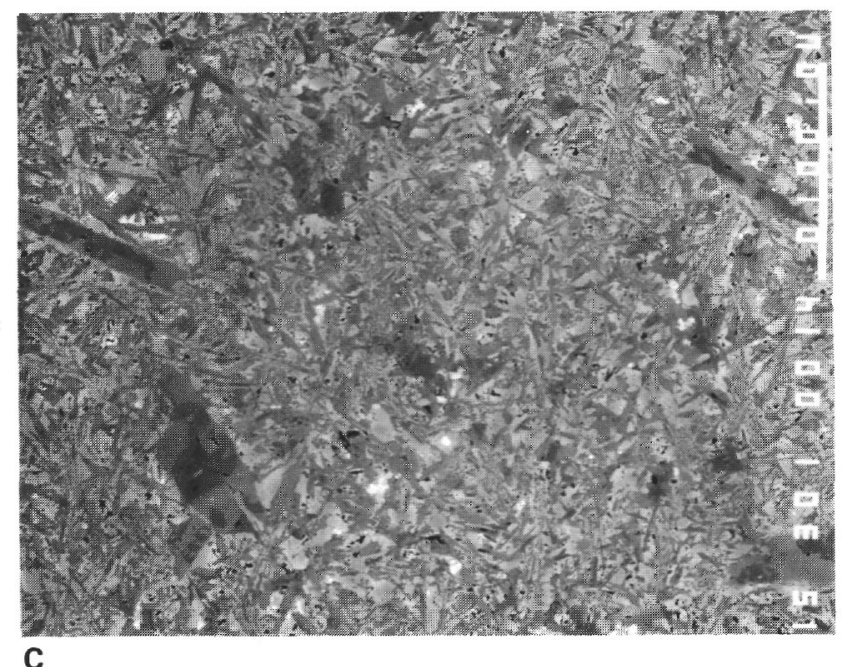

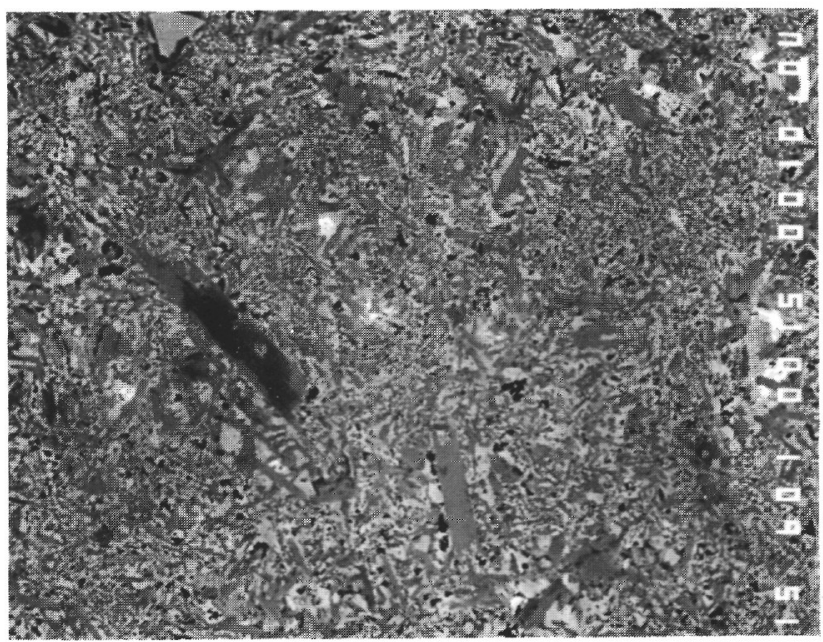

B

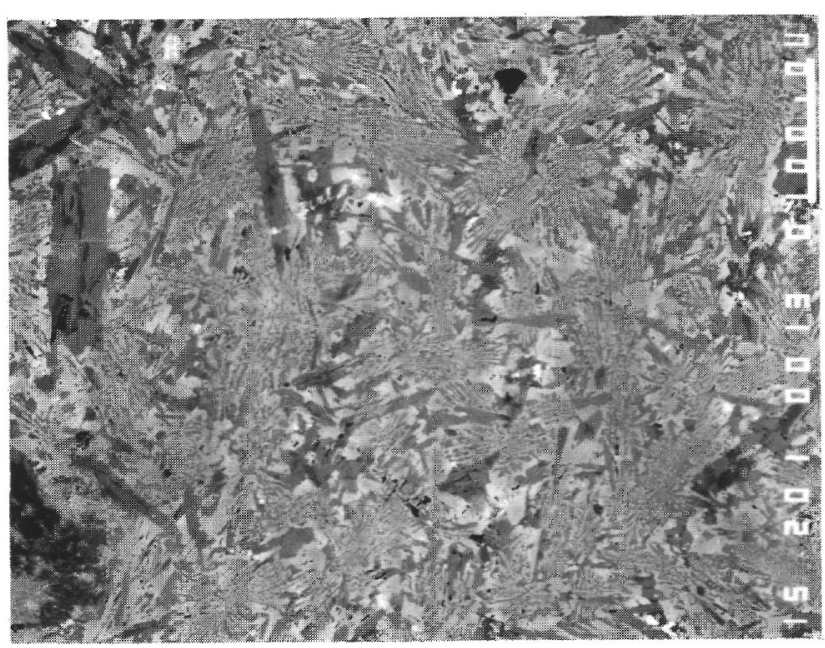

D

Figure 10. BEI photos of Zones $2 \mathrm{~b}$ and 6 in planar dike margin. Sample 504B-101-1, 76-79 $\mathrm{cm}$. (A) Zone 2b, cryptocrystalline prophyrotopic. FeTi-oxides = white, clinopyroxene = light gray, Ca-plagioclase = intermediate gray, alteration of plagioclase/laumontite $?=$ dark gray, alteration of olivine/phyllosilicates = black. (B) Higher magnification BEI photo of cryptocrystalline porphyrotopic Zone $2 \mathrm{~b}$ demonstrating the spectrum of grain sizes and crystal morphologies. Note absence of dendritic or spherulitic growth. (C) Zone $2 \mathrm{~b}$ adjacent to Zone 6 . (D) Zone 6 consisting of coarse-grained tabular plagioclase and equant clinopyroxene with interstitial plumose to bowtie-spherulitic intergrowths of plagioclase and clinopyroxene.

process within conduit systems. Secondly, this derivation does not account for nucleation on a preexisting substrate, the process most likely for natural systems (Jackson, 1977; Kirkpatrick, 1974, 1976). The formation of nuclei on preexisting solid phases can greatly reduce the surface energy associated with the nucleus (Dowty, 1980; Lofgren, 1982). At present the mechanism of heterogeneous nucleation cannot be adequately represented theoretically since the difference of surface energy is dependent on the physical state as well as the structural complexity of the substrate.

Lofgren (1980) has stated from experimental observations that the nucleation behavior including any or all of the incubation time, rate, density, or distribution appears to be the most important variable in determining the growth kinetics and rock textures. He has shown that olivine and oxides nucleate most easily, followed by clinopyroxene and plagioclase presumably because of the increasingly polymerized structures represented in this sequence. In addition, for heterogeneous nucleation, the more polymerized the structure of the nucleating phase, the more polymerized the structure of the substrate must be. Thus, plagioclase appears to nucleate only on itself, although clinopyoxene or olivine may nucleate on plagioclase.

Moreover, a time lag exists between the inception of nucleation and the point at which the steady-state rate is achieved. This could become extremely important at rapid cooling rates. Kaschiev (1969) derived an expression for this time lag, $\tau$, and found that it is directly proportional to temperature, but inversely proportional to the surface area, the exponential of the activation energy and the free energy versus cluster size function. Kirkpatrick (1983) observed that the most important parameters affecting the time constant are the activation energy and the shape of the free energy versus cluster radius curve near 
the critical values. Kaschiev (1969) determined that $t$ must equal $5 \tau$ before the steady-state rate is achieved.

The process of crystal growth under various conditions is better understood because its effects can be observed microscopically. The theoretical derivations for growth rate are similar to those for nucleation rate. Both are functions of the deviation from the equilibrium or liquidus temperature, $\mathrm{T}_{e}$ (which is called the undercooling, $\Delta \mathrm{T}$ ), and the cooling rate; $d \mathrm{~T} / d \mathrm{t}$. Qualitatively, these two parameters dictate that the rates of nucleation are zero at the liquidus $(\Delta T=0)$ because the driving force, $\Delta G$, is small. As $\Delta \mathrm{T}$ increases, $\Delta G$ and both nucleation and growth rates increase to a maximum. Beyond these maxima the rates decrease due to the countering effects of drastically reduced diffusion rates. The steady-state maximum in nucleation rate is generally at a larger undercooling than that of growth rate (Kirkpatrick, 1976). However, for natural systems the difference may not be as great due to nucleation on foreign substrates, that is, heterogeneous nucleation. Moreover, if the cooling rate is large, the conditions will be too transient for the predicted nucleation and growth rates to be achieved.

\section{DISCUSSION}

The cooling histories indicated by the crystal morphologies in pillow margins have been discussed in depth by Kirkpatrick (1978). In his model, the textural sequence observed is the product of an intimate interplay of cooling rate and the degree of undercooling such that at any one position in the pillow the absolute undercooling changes as cooling proceeds. The rate at which this takes place varies from pillow to pillow, but, in general, both undercooling and cooling rate are large. Walker et al. (1976) recorded the temperature of appearance of the crystalline phases in lunar picritic basalt 12002 as a function of cooling rate and found that increasing cooling rate can progressively reduce the temperature of appearance of a phase and eventually suppresses its appearance completely. Such is the case in Zone 1 of both dike and pillow margins. In this zone glass forms because the temperature drops so rapidly through the nucleation and growth curves that few crystals nucleate or grow. Similarly, in Zone 2 of pillow margins isolated spherulites set in a matrix of glass suggest that only minimal amounts of growth and nucleation are possible. Moreover, detailed examination of the spherulites indicates that nucleation is only accelerated by means of heterogeneous nucleation. Although the spherulites have plagioclase microlites in the centers, the major portion of the spherulitic overgrowth is clinopyroxene that initially nucleated on the plagioclase. The experimental work of Walker et al. (1976) suggested that the degree of suppression is least for the liquidus phase and greatest for the lowest temperature phase. Yet in Leg 83 basalts, clinopyroxene crystallizes well below the equilibrium liquidus temperature after plagioclase and olivine have begun to crystallize (Autio and Rhodes, 1983). This reversal is in all probability due to the fact that the degree of suppression is also a function of the incubation time for nucleation and in turn a function of the crystal structure complexity; highly polymerized minerals like feldspar require more time for nucleation than olivine or clinopyroxene. Thus, homogeneous nucleation of the crystallizing phases is apparently insignificant in this zone; the lower energy barrier to nucleation on a preexisting substrate favors those phases that can nucleate by this mechanism. In addition, the growth is not an equilibrium process leading to formation of rational crystal faces. Rather, growth occurs by the repeated breakdown of the crystal interface into dendrites or spherulites whose fibers or needles grow rapidly outward to overcome the effects of slow diffusion rates at low temperatures. Thus, crystals with simpler structures grow preferentially over more complex ones regardless of the equilibrium crystallization sequence under these rapid cooling conditions.

Decreased undercoolings and lower $d \mathrm{~T} / d \mathrm{t}$ are indicated in Zone 3 by the diminishing abundance of glass, the concurrent increase in size of the clinopyroxene dominated spherulites, and the appearance of olivine dendrites. The olivine dendrites represent the first phase to nucleate homogeneously under the rapidly changing conditions prevailing in the pillow margins. Plagioclase also forms more dendritic crystals as well, but its growth is inhibited by the encompassing spherulites. In Zone 4, progressively smaller values of $\Delta \mathrm{T}$ and $d \mathrm{~T} / d \mathrm{t}$ result in conditions conducive for plagioclase growth; clinopyroxene dominance in the crystallization is reduced and extensive plagioclase bowtie spherulites or sheaf textures are produced. Within the pillow interior progressively lower values provide a closer approach to equilibrium conditions, and clinopyroxene is restricted to crystallization between skeletal to tabular plagioclase laths. The change in olivine morphology with changing undercooling and cooling rate is difficult to assess for these samples due to its complete alteration to smectite, chlorite, or talc.

The textures observed in pillow margins from Hole 504B indicate that they formed by a combination of large undercooling and rapid cooling rate such that nucleation and growth are completely suppressed in the outermost portions of the rim. Nucleation is largely restricted to a heterogeneous mechanism, and appearance of phases is a function of the type of substrate available as well as the variation in temperature conditions. The high cooling rate in pillows precludes achievement of the maximum steady-state nucleation rate in any of the outer zones.

In common with pillow margins, dike margins demonstrate textures indicative of significant deviations from the equilibrium temperature and a progressive decrease in undercooling and cooling rate away from the margin. In contrast to pillow margins, the average values for these parameters are much smaller. In addition, the interplay between cooling rate and undercooling is such that nucleation more closely approaches the maximum steady-state rate. Thus, nucleation density far surpasses that in pillow margins. Ultimately, this nucleation history has a profound effect on the textures produced during subsequent cooling.

Aside from the exceptional glass of Zone 1, Zone 2 represents the greatest undercooling and fastest cooling rate in the dike margin. In pillow margins, glass and dendritic or spherulitic crystal morphologies were produced in the zones with the largest undercooling and 
cooling rates. Yet the textures in Zone 2 of the dike margins are fine grained and cryptocrystalline ranging from equigranular to porphyrotopic. There is no suggestion of heterogeneous nucleation as in the pillow margins, nor is there development of skeletal or dendritic crystal morphologies, although these appear toward the interior of the dikes. This seemingly paradoxical result is a function of the much smaller undercooling and cooling rates in the dikes as compared to pillow margins. Because these conditions permit a closer approach to the maximum steady-state nucleation rate, the nucleation density is higher. As a result, little diffusion is necessary for a given element to reach a suitable substrate. Growth rate is slowed as grain boundaries of adjacent crystals rapidly impinge upon each other.

Furthermore, unlike pillow margins where plagioclase nucleation and crystallization are suppressed for several millimeters away from the rim, plagioclase nucleation in dike margins is abundant and its growth is initially uninhibited by heterogeneous nucleation of clinopyroxene. Apparently sufficient incubation time is available under these cooling conditions for nucleation of this highly polymerized phase.

Similarly for Zone 3, although the spheruloids present are reminiscent of the textural sequence observed in pillows, these features reflect markedly different conditions from the pillow margins. The spheruloids do not possess a radial arrangement of crystals; rather, they are spherical clusters of crystals not unlike the cryptocrystalline matrix in which they are set. Clinopyroxene commonly occurs in enhanced concentrations at the spheruloid boundaries. This suggests that local chemical variations initiated by the growth of the plagioclase crystallite resulted in more intense nucleation of clinopyroxene in the diffusion boundary layer adjacent to the plagioclase. Analogous to Zone 2, the high nucleation rate negates the necessity for crystallization of radiating or branching crystals.

In Zone 4, the spheruloids take on a subtle radiate habit, and the average crystal size of individual crystals in the spheruloids is slightly larger. The continuation of this trend in Zone 5 leads to the formation of true spherulites. Thus, although both cooling rate and undercooling are less than in the previous zones, so also is the nucleation rate. With fewer nuclei present, the material rejected during growth of the crystallizing phases builds up at the crystal/melt interface faster than it can diffuse away or attach to a suitable substrate, and elongate crystals morphologies result.

Zone 6 is characterized by the initiation of crystallization of crystals that are larger, more equant, and/or faceted. It is interesting that this occurs initially at the margins of the multiphase spherulites or plumose growth in both planar and irregular margins. The apparent optical continuity from plumose or spherulitic growth to coarse-grained margins implies that the larger crystals formed subsequently to the spherulitic or plumose textures. However, this is contrary to the sequence expected from crystallization of melt with increasing undercooling. This phenomenon is attributed to recrystallization. Theories modeling the mechanism of crystal growth (Jackson, 1958) and subsequent experimental work (Nabelek et al., 1978; Jackson et al., 1967) have shown that spherulitic or dendritic crystal morphologies with their higher surface area and subsequently higher surface free energy are not the thermodynamically preferred morphologies. Thus, in a dike where magma at or near the liquidus temperature may occupy the center of the conduit long after crystallization of the margins has occurred, elevated temperatures could be maintained long enough for these metastable morphologies to be at least partially replaced by more thermodynamically stable (lower surface free energy) forms. Within the dike interior where the smallest undercoolings and cooling rates occur, textural relations indicate that plagioclase crystallized first as skeletal microlites and clinopyroxene nucleated subsequently in the interstitial volumes among the plagioclase crystals.

Petrographic analysis of pillow and dike margins from Hole 504B indicates that these dike and pillow chilled margins have undergone markedly different nucleation and growth histories. One of the most obvious products of this difference is the greater nucleation density in dikes as opposed to pillow chilled margins. However, if the chilled intrusive margins recovered are truly the feeder system of the overlying pillow units, this requires that the magma extruded as pillow lavas did not experience the same extensive nucleation event. Alternatively, the recovered chilled margins are not the feeders for the pillows.

Evidence that the margins recovered are not the feeders for the pillows is principally derived from Sample 504B-129-3, 30-36 cm, in which both margins of an 8 -mm-wide dikelet were recovered (Fig. 6D). The sequence of textures observed in this sample is similar to that described for irregular dike margins. This suggests that chilled margins of this type are small intrusive features, probably projections from larger dikes. The difference in textures observed for irregular and planar margins are thus most likely a matter of scale, the planar margins being produced by larger dikes. These larger dikes cannot be ruled out as potential feeders for the pillows.

It is proposed that the lavas rise to the surface without the nucleation event exhibited in the dike margins. Computer modeling of the crystallization of a hypothetical 2-m-wide dike by Kirkpatrick (1976) yielded the result that the first $1-2 \mathrm{~cm}$ of the dike would crystallize within a few hours after injection. Since the width of the chilled margins recovered in drill core is also on the order of $1-2 \mathrm{~cm}$ wide, it is likely that the textures observed are those produced during the first few hours, while the interior of the conduit continues to flow to the surface with few or no nuclei formed.

\section{SYNTHESIS}

The distinctive petrographic features of dike and pillow margins have been outlined for samples recovered during DSDP Leg 83. These textural characteristics were applied to rapidly cooled samples recovered from Hole 504B to ascertain whether rocks obviously representing some type of chilled margin were emplaced as dikes or as pillows where actual contacts were not recovered intact. The first dike in Hole 504B was encountered during Leg 70 at a depth of $712 \mathrm{~m}$ (below seafloor), and 
dikes were encountered with increasing frequency during Leg 83 below $837 \mathrm{~m}$; the last pillow was recovered at $1047 \mathrm{~m}$. These observations combined with geophysical data determined for Hole 504B (hole summary chapter, this volume) enabled division of the encountered units into three zones. The upper zone, Layer 2A, consists of $573 \mathrm{~m}$ of intercalated pillow lavas with hyaloclastites, minor flows, and localized flow breccias. The middle or transition zone, Layer 2B, contains approximately $210 \mathrm{~m}$ of pillows, minor flows, and dikes while the lowermost zone, Layer $2 \mathrm{C}$, recovered in excess of $300 \mathrm{~m}$ of massive units and dikes.

The distinctive textural features of dike and pillow chilled margins have also been qualitatively interpreted in terms of their nucleation and growth histories as a function of undercooling and cooling rate. The textures observed in pillow margins studied indicate that they formed by a combination of large undercooling and rapid cooling rate such that nucleation and growth are completely suppressed in the outermost portions of the rim. Nucleation is largely restricted to a heterogeneous mechanism, and appearance of phases is a function of the type of substrate available as well as the variation in temperature conditions. The high cooling rate in pillows precludes achievement of the maximum steady-state nucleation rate in any of the outer zones. On the other hand, the smaller undercooling and cooling rates appropriate to dike chilled margins result in a nucleation rate that more closely approaches the maximum steady state. Although growth rate is theoretically predicted to be faster under analogous conditions, the higher nucleation density in effect suppresses the growth rate as the crowded crystallite grain boundaries rapidly impinge. The slow cooling rates produced in dikes result in elevated temperatures sustained for significant lengths of time. This permits at least partial recrystallization of the metastable crystal morphologies that are initially produced during crystallization.

\section{ACKNOWLEDGMENTS}

The author wishes to thank N. H. Gray for his careful review of this paper. This work was partially funded by the Institute for the Study of Earth and Man, Southern Methodist University.

\section{REFERENCES}

Autio, L., and Rhodes, J. M., 1983. Costa Rica Rift zone basalts: geochemical and experimental data from a possible example of multistage melting. In Cann, J. R., Langseth, M. G., Honnorez, J., Von Herzen, R. P., White, S. M., et al., Init. Repts. DSDP, 69: Washington (U.S. Govt. Printing Office), 729-746.

Bence, A. E., and Albee, A. L., 1968. Empirical correction factors for the electron microanalysis of silicates and oxides. J. Geol., 76:382.

Bryan, W. B., 1972. Morphology of crystals in submarine basalts. $J$. Geophys. Res., 77:5812-5819.

Bryan, W. B., and Moore, J. G., 1977. Compositional variations of young basalts in the Mid-Atlantic Ridge rift valley near latitude $36^{\circ} 40^{\prime}$ N.Geol. Soc. Am. Bull., 88:556-570.

Cann, J. R., 1974. A model for ocean crust structure developed. Geophys. J. R. Astron. Soc., 39:169-187.

Dewey, J. F., and Kidd, W. S. F., 1977. Geometry of plate accretion. Geol. Soc. Am. Bull., 88:960-968.

Donaldson, C. H., Usselman, T. M., Williams, R. J., and Lofgren, G. E., 1975. Experimental modeling of the cooling history of Apollo 12 olivine basalts. Sixth Lunar Sci. Conf. Proc., pp. 843-870.

Dowty, E., 1980. Crystal growth and nucleation theory and the numerical simulation of igneous crystallization. In Hargraves, R. B.
(Ed)., Physics of Magmatic Processes: Princeton, N. J. (Princeton University Press), pp. 419-486.

Dowty, E., Keil, K., and Prinz, M., 1974. Lunar pyroxene-phyric basalts: crystallization under supercooled conditions. J. Petrol., 15: 419-453.

Friedman, G. M., 1965. Terminology of crystallization textures and fabrics in sedimentary rocks. J. Sed. Petrol., 35:643-655.

Gray, N. H., 1970. Crystal growth and nucleation in two large diabase dikes. Can. J. Earth Sci., 7:366-375.

, 1978. Crystal growth and nucleation in flash-injected diabase dikes. Can. J. Sci., 15:1904-1923.

Hall, M. G., and Lloyd, G. E., 1981. The SEM examination of geological samples with a semiconductor back-scattered electron detector. Am. Mineralogist, 66:362-368.

Houtz, R., and Ewing, J., 1976. Upper crustal structure as a function of plate age. J. Geophys. Res., 81:2490-2498.

Jackson, K. A., 1958. Mechanisms of growth in liquid metals and solidification. Metals park, Ohio, Am. Soc. Metals, pp. 174-186. , 1977. Nucleation and atomic kinetics. In Bardsley, W., Hurle, D. T. J., and Mullins, J. B. (Eds.), Crystal Growth: A Tutorial Approach: (North-Holland Series in Crystal Growth) NorthHolland, N. Y. 2: 139-156.

Jackson, K. A., Uhlman, D. R., and Hunt, J. D., 1967. On the nature of crystal growth from the melt. J. Crystal Growth, 1:1-36.

Kaschiev, D., 1969. Solution of the non-steady state problem in nucleation kinetics. Surface Sci., 14:209-220.

Kirkpatrick, R. J., 1974. Kinetics of crystal growth in the system $\mathrm{CaMgSi}_{2} \mathrm{O}_{6}-\mathrm{CaAl}_{2} \mathrm{SiO}_{6}$. Am. J. Sci., 274:215-242.

, 1976. Towards a kinetic model for the crystallization of magma bodies. J. Geophys. Res., 81:2565-2571.

, 1978. Processes of crystallization in pillow basalts, Hole 396B, DSDP Leg 46. In Dmitriev, L., Heirtzler, J., et al., Init. Repts. DSDP, 46: Washington, (U.S. Govt. Printing Office), 217-282. , 1981. Kinetics of crystallization of igneous rocks. In Lasaga, A. C., and Kirkpatrick, R. J. (Eds.), Kinetics of Geochemical Processes. Michigan (Bookcrafters, Inc.), pp. 321-398.

1983. Theory of nucleation in silicate melts Am. Minerologist, 68:66-77.

Lane, A. C., 1898. Geology report on Ilse Royal, Michigan. Geol. Surv. Mich., VI: 123-151.

Lofgren, G. E., 1975. Dynamic crystallization experiments on mare basalts. Origin of Mare Basalts: Houston (LPSI), pp. 99-103.

,1980. Experimental studies on the dynamic crystallization of silicate melts. In Hargraves, R. B. (Ed.), Physics of Magmatic Processes: Princeton, N. J. (Princeton University Press), pp. 487-551. 1982. The process of heterogeneous nucleation in basaltic magmas. Geol. Soc. Am. Abstract with Programs, 14:548.

Lofgren, G. E., and Donaldson, C. H., 1975. Phase relations and nonequilibrium crystallization of ocean ridge thoeleiite from the Nazca plate. EOS Trans. AGU, 59:396. (Abstract)

Moores, E. M., and Vine F. J., 1971. Troodos massif, Cyprus and other ophiolites as oceanic crust: Evaluations and implications. Philos. Trans. R. Soc. London, Ser. A., 268:443-466.

Nabelek, P. I., Taylor, L. A., and Lofgren, G. E., 1978. Nucleation and growth of plagioclase and the development of textures in a high-alumina basaltic melt. Ninth Lunar Sci. Conf. Proc., 725-741.

Orcutt, S. A., Kennett, B. L. N., and Dorman, L. M., 1976. Structure of the East Pacific Rise from an ocean bottom seismometer survey. Geophys. J. R. Astron. Soc., 45:305-320.

Pallister, J. S., and Hopson, C. A., 1981. Samail ophiolite plutonic suite: Field relations, phase variations, cryptic variation and layering, and a model of a spreading ridge magma chamber. J. Geophys. Res., 86:2593-2644.

Queneau, A. L., 1902. Size of grains in igneous rocks in relation to the distance from the cooling wall. Columbia Univ. School of Mines Quart., 23:181-195.

Schiffman, P., and Lofgren, G. E., 1982. Dynamic crystallization studies on the Grande Rhode pillow basalts, central Washington. $J$. Geol., 90:49-78.

Walker, D., Kirkpatrick, R. J., Longhi, J., and Hays, J. F., 1976. Crystallization history of lunar picrite basalt sample 12002: phase equilibria and cooling rate studies. Geol. Soc. Am. Bull., 87: 646-656.

Date of Initial Receipt: 8 April 1983

Date of Acceptance: 2 December 1983 